\title{
Geochronological systematics of the Huayna Potosí, Zongo and Taquesi plutons, Cordillera Real of Bolivia, by the $\mathrm{K} / \mathrm{Ar}, \mathrm{Rb} / \mathrm{Sr}$ and $\mathrm{U} / \mathrm{Pb}$ methods
}

\author{
Umberto Giuseppe Cordani ${ }^{*}$ (D), Alvaro Rodrigo Iriarte ${ }^{1,2}$ (D), Kei Sato ${ }^{1}$
}

\begin{abstract}
The Huayna Potosi, Zongo and Taquesi are Triassic plutons located at the core of the Real Cordillera of Bolivia. In this paper, several Rb-Sr and K-Ar ages obtained in the past at the São Paulo Geochronology Laboratory, yet unpublished, will be presented, along with newer U-Pb Sensitive High-Resolution Ion Microprobe (SHRIMP) determinations made in the same laboratory, allowing us to redefine the geologic history of this part of the Central Andes. $\mathrm{Rb} / \mathrm{Sr}$ analyses of some low grade metapelitic country rocks of the early Paleozoic (Amutara and Cancañiri Formations) yielded a Rb-Sr isochron age of $344 \pm 38 \mathrm{Ma}$, indicating the action of an early Gondwanide regional event. A five-point $\mathrm{Rb}$-Sr isochron from a granite outcrop of the Huayna Potosi pluton yielded an age of $224 \pm 28 \mathrm{Ma}$. In addition, an important Ar loss in micas was detected in the Zongo granitoids and their country rocks, recording a thermal event that opened this isotopic system in the Oligocene. Newer U-Pb SHRIMP zircon ages of ca. $221 \mathrm{Ma}$ were obtained in two other granitic outcrops of the Huayna Potosi granite. They confirmed its Triassic crystallization age, and a similar U-Pb SHRIMP age of 221.9 $\pm 1.5 \mathrm{Ma}$ was obtained for one sample of the Taquesi pluton. For the Zongo pluton, many of the zircon grains obtained from one sample of its Kuticucho facies yielded extremely high uranium content, which produced reverse discordant apparent ages. However, due to the fair alignment of the analytical points in the Concordia diagram, possibly corresponding to a linear correlation, we made a regression calculation and the interception of the Concordia curve resulted in a rather imprecise age of $220 \pm 20 \mathrm{Ma}$. Our conclusion was that the final magmatic crystallization and the intrusion of plutons in the central part of the Cordillera Real of Bolivia have occurred close to $221.5 \pm 2.0 \mathrm{Ma}$, in late Triassic times. Finally, the U-Pb SHRIMP ages obtained in inherited zircon xenocrysts from the four available granitic rocks yielded very different ages, and many of them are related to previous magmatic episodes of the Andean Tectonic System. A few other age measurements indicated sources related to much older Proterozoic magmatic events associated with rocks from the Andean basement.
\end{abstract}

KEYWORDS: Granitoids; Real Cordillera; SHRIMP; zircon.

\section{INTRODUCTION}

The first dating of the Huayna Potosí pluton of the Cordillera Real of Bolivia (Fig. 1) was found by Evernden et al. (1977) using a few K/Ar measurements in micas. In 1978, the first author of this study provided a training course in geochronology in La Paz related to Proyecto Cordillera of GEOBOL (the Geological Service of Bolivia). A field trip took place in such occasion, where several samples were taken along a SW-NE geological profile, from the Milluni Mine, located within the sedimentary country rocks, near the southern contact of the Huayna Potosí pluton, to the limits of the Zongo pluton at Sainani (Figs. 2 and 3). At that

${ }^{1}$ Universidade de São Paulo - São Paulo (SP), Brazil.E-mails: ucordani@usp.br, kei@usp.br, arodrigoiriarte@usp.br

${ }^{2}$ Universidad Mayor de San Andrés - La Paz, Bolivia.

${ }^{*}$ Corresponding author.

C) 2019 The autors. This is an open access article distributed under the terms of the Creative Commons license. time, a series of samples was analyzed at the University of São Paulo laboratory, by the $\mathrm{Rb} / \mathrm{Sr}$ and $\mathrm{K} / \mathrm{Ar}$ methods, and a presentation was made at the Symposium on the "Magmatic Evolution of the Andes" within the International Geological Congress held in Paris, France, in 1980 (Cordani et al. 1980). This presentation had the support of only an abstract, which shall be considered as a preliminary geological piece of information for the region of interest. Later, other $\mathrm{K} / \mathrm{Ar}$, as well as $\mathrm{Ar} / \mathrm{Ar}$ analyses were made for the Zongo granite (McBride et al. 1983, 1987, Kennan et al. 1995). Moreover, Farrar et al. (1990) and Gillis et al. (2006) dated several plutons of the Real Cordillera using the $\mathrm{U} / \mathrm{Pb}$ method in zircon for the first time.

The preliminary results obtained on the old samples collected in 1978, as well as the additional geochronological work carried out later, had left important uncertainties about the tectonic history of the Cordillera Real. Therefore, in order to contribute to achieve a better understanding of it, our decision was to make some effort to constrain the crystallization age of the Huayna Potosi, Zongo and Taquesi plutons, located not far from each other, in the central part of the Cordillera Real, by means of a few robust 
$\mathrm{U}-\mathrm{Pb}$ determinations on zircon. Thus, three samples of typical granitic rocks from large and fresh outcrops of Huayna Potosi and Zongo plutons (RIB-2, 4 and 5) were collected in 2016, following the same road along the Zongo River, where the first sample recollection was done in 1978. An additional sample (RIB-11) was collected from the nearby Taquesi pluton to the SE of the Zongo river. Zircon crystals were extracted from each sample for age dating and were carried out employing the Sensitive High-Resolution Ion Microprobe (SHRIMP) instrument at the Geochronology Research Center (CPGeo) of the Universidade de São Paulo (USP).

The purpose of this article is to present a comprehensive review of the age dating available for these granitic plutons, recovering the ancient geochronological data produced in São Paulo and adding the ones made by Evernden et al. (1977), McBride et al. (1983, 1987), Kennan et al. (1995), Farrar et al. (1988) and Gillis et al. (2006), as well as the new $\mathrm{U}-\mathrm{Pb}$ zircon data. An attempt is made to interpret the magmatic setting and the geologic history for this part of the Cordillera Real of Bolivia.

\section{GEOLOGICAL BACKGROUND}

The Cordillera Real forms a prominent part of the mountainous relief of the Andes, at the core of the Eastern Cordillera of the Central Andes (Figs. 1 and 2), with a length of $250 \mathrm{~km}$ along strike and $40 \mathrm{~km}$ wide, and presenting a few peaks with an altitude of more than 6,000 meters above the sea level. In the tectonic map of South America (CGMW 2016), it is located within the Eastern Cordillera back thrust zone, where thrust faults have a general vergence to the west (Dorbath et al. 1993, McQuarrie et al. 2002, Gillis et al. 2006) and were formed by compressive tectonism during the Oligocene (Sergeotecmin 2011). Major acidic magmatism is present, which was formed in two pulses from the available ages. The first one had a long duration (280-200 Ma) and occupied most of the Permian and Triassic, and the later occurred in a short time in the Oligocene (23-26 Ma).

The older plutons, Huato, Illampu, Yani, Huayna Potosí, Zongo and Taquesi, are located to the North of 16\%30' and the Oligocene plutons, Illimani, Quimsa Cruz and Santa Vera Cruz, are located to the South of this latitude. All of them present a variety of granitoid rocks, such as granodiorites,

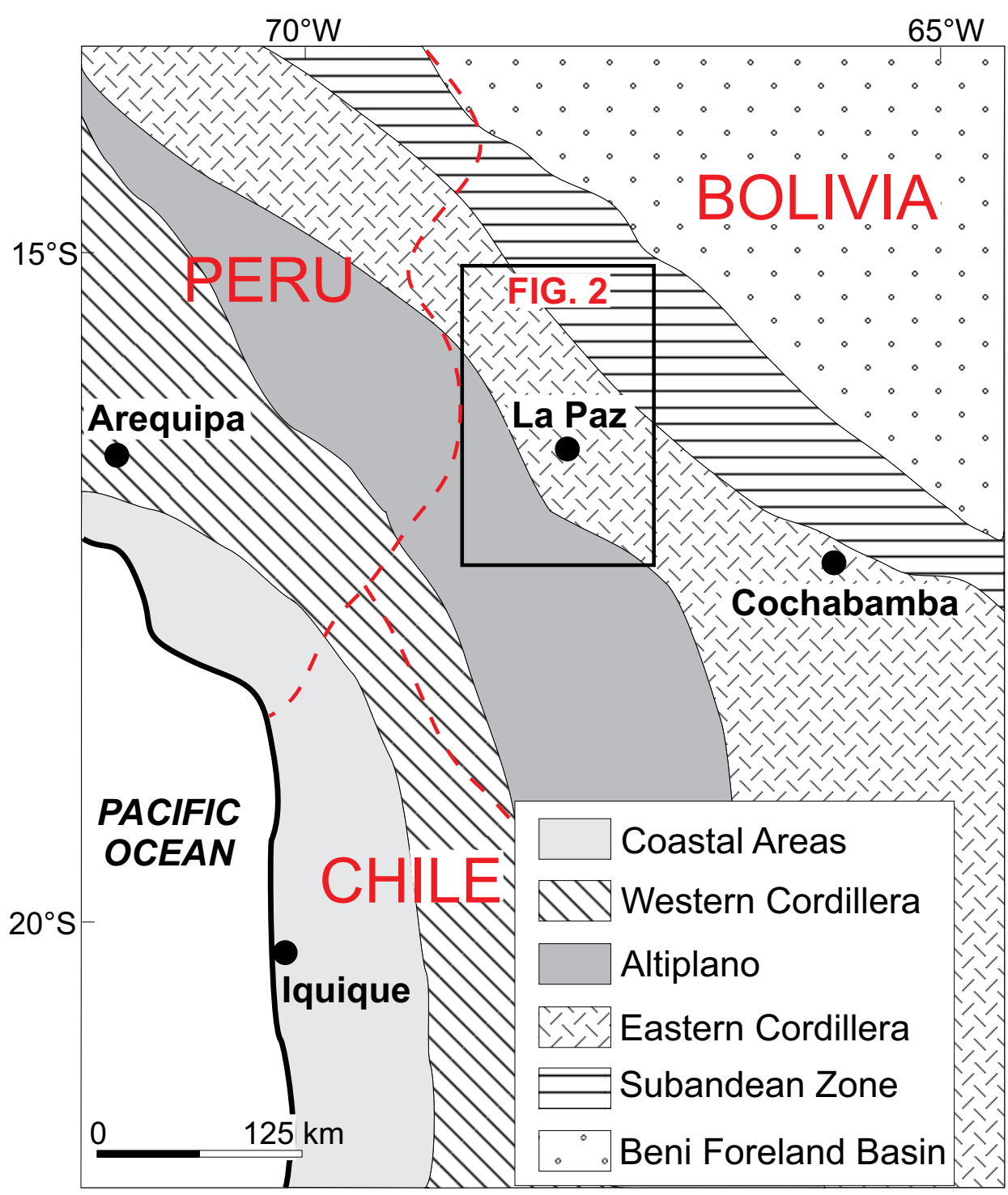

Figure 1. Simplified tectonic setting of the Central Andes, showing the present study site. 


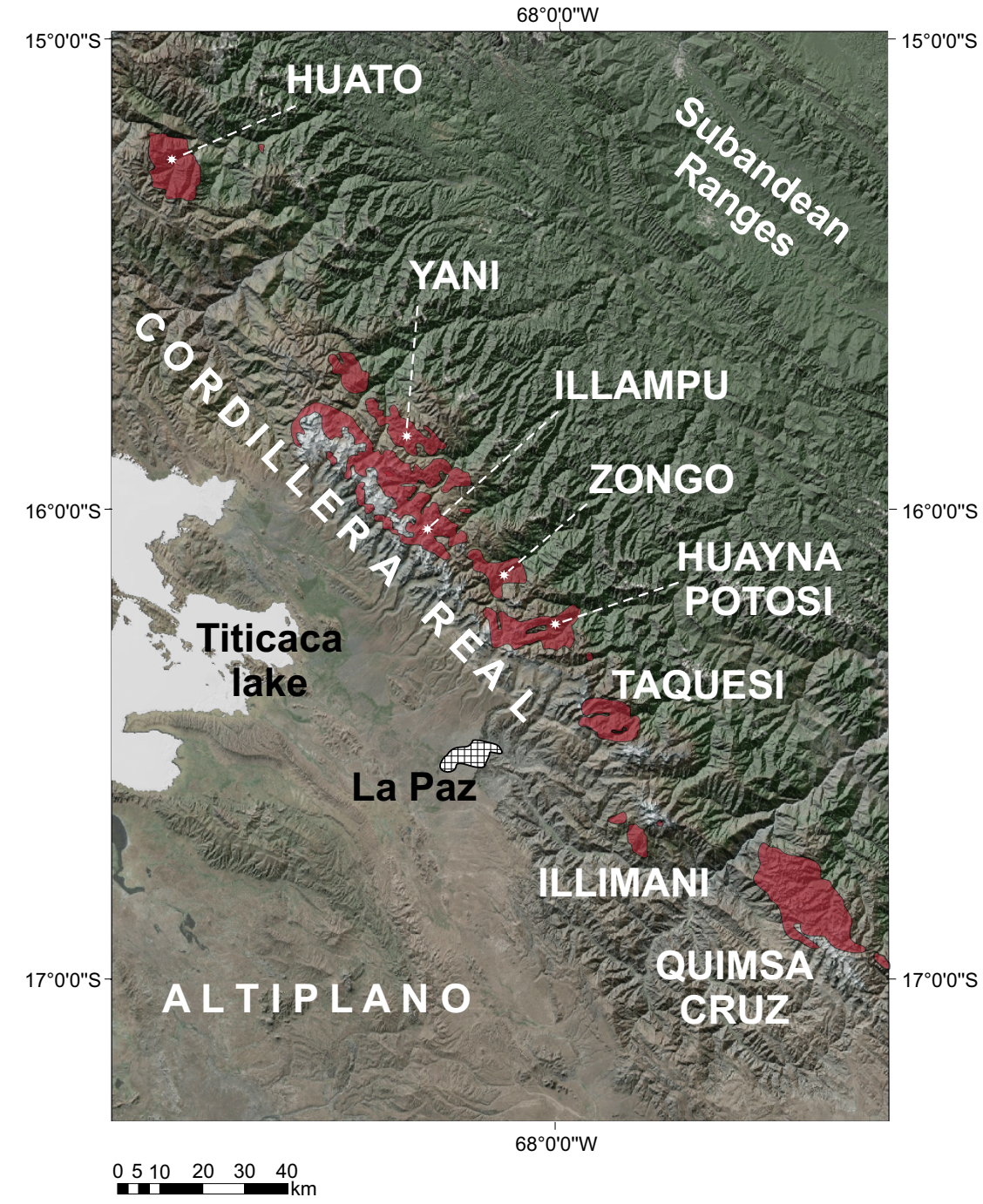

Figure 2. Location of the granitic plutons of the Cordillera Real of Bolivia, within the Eastern Cordillera.

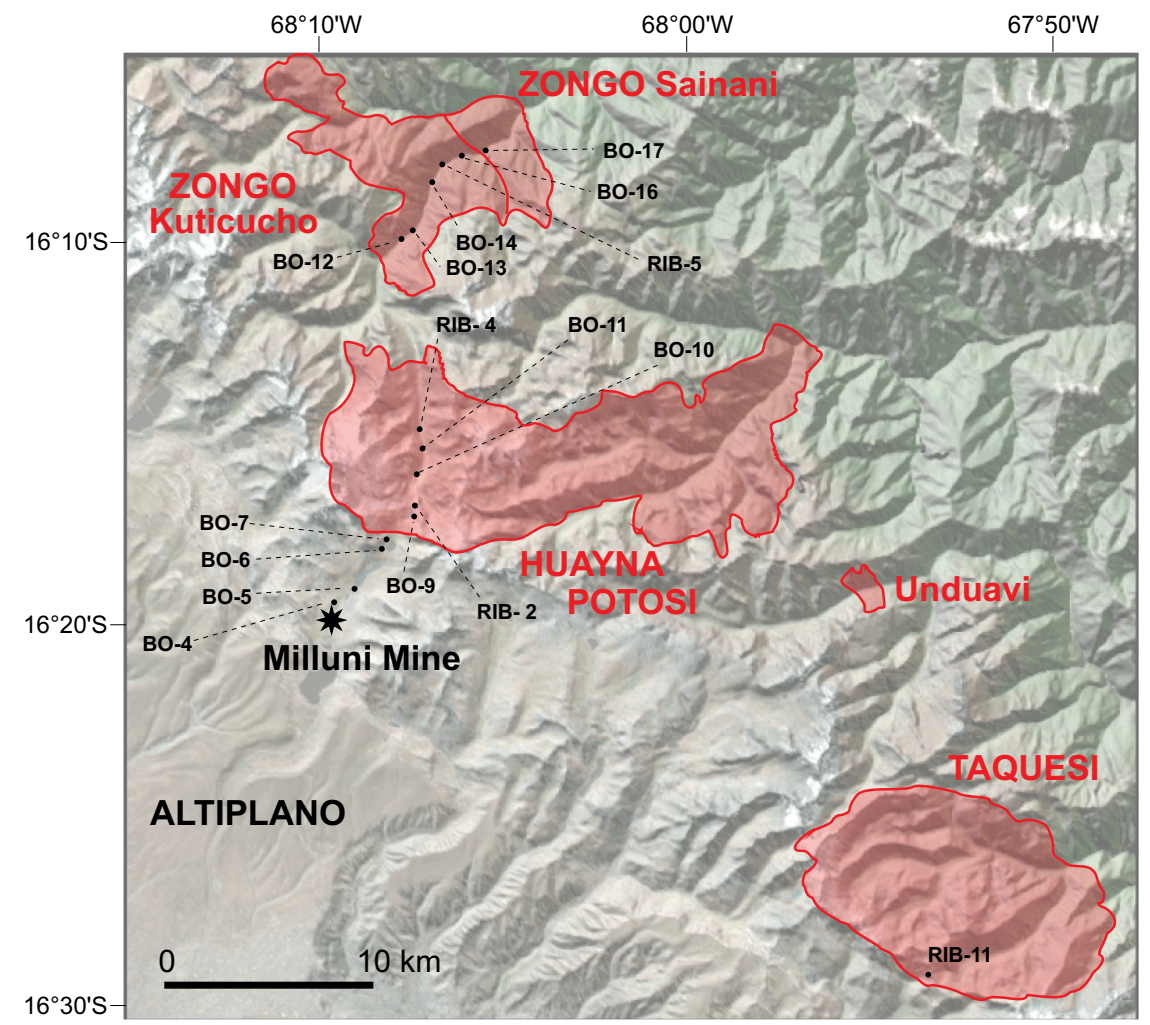

Figure 3. Geological map of the Huayna Potosi and Zongo plutons, with the location of the samples collected in 1978 (BO-4 and others) and 2016 (RIB-2, 4 and 5), along the road following the Zongo river. 
quartz monzonites, and granites. Within the country rocks, Ordovician and/or Silurian metasedimentary pelites predominate. They correspond to Ordovician metapelites of the Amutara and Coroico formations and to Silurian siltstones, slates, glacimarine deposits and sandstones of the Cancañiri, Catavi, Uncia and Llallagua formations.

Following the review made by Ramos (2018a) on the tectonic evolution of the Central Andes, the Phanerozoic tectonic history of the Cordillera Real could be briefly resumed as follows:

- From the late Neoproterozoic until middle-late Devonian times, the Famatinian orogenic cycle affected the entire proto-Pacific margin of South America, from Venezuela to Argentina (Ramos 2018b). In the Central Andes, metamorphic rocks and orthogneisses with Famatinian ages were identified within the northern part of the Eastern Cordillera of Peru, where the orogen was controlled by the old Grenvillian sutures. During the early Paleozoic, a thick sequence of Ordovician to Devonian sediments was deposited over continental basement in that region, in Peru and Bolivia, as a retro-arc basin of the Famatinian Orogeny (Sempere 1995);

- Later, starting in the early Carboniferous, the Gondwanide Orogeny, a strong and widespread intra-plate tectonic episode, affected most of the Andean realm of South America and was well represented in the Eastern Cordilleras of Peru and Bolivia (Dalmayrac et al. 1980). The Famatinian retro-arc basin underwent deformation, metamorphism, and granitic intrusions in two tectonic phases, 336-285 Ma and 280-235 Ma (Miskovic et al. 2009), known as the early and the late Gondwanide orogenies. They were practically coeval to the Hercynian continental collisions that formed the Pangea supercontinent;

- In the late Permian, the southern continents were subjected to a series of extensional episodes that started the breakup of Pangea. Pre-existing crustal weakness zones controlled the location of the main extensional systems (Ramos 2009). As to the Eastern Cordillera of Peru and Bolivia, the rift basins and associated igneous rocks, such as the volcano sedimentary sequences of the Mitu Group of SE Peru, followed the inherited terrane boundary represented by the ancient suture formed during Grenvillian times between the Arequipa Terrane and the Amazonian Craton, which was extensionally reactivated during the Famatinian. Mpodozis and Kay (1992) indicated that the associated volcanic rocks of the Choiyoi can be followed from South America to Antarctica at the SW border of Gondwana;

- In Triassic times, after the late Gondwanide Orogeny, a series of granitic plutons intruded along extensional tectonic zones the early Paleozoic retro-arc platform in the Cordillera de Carabaya in Peru and in the Cordillera Real of Bolivia (Spikings et al.2016), such as the peraluminous granitoid rocks dealt in this paper. Several plutons, mainly leucogranites, lacking subduction signature, were interpreted as due to magmatism occurred after the detachment of a previously formed subducting oceanic slab (Miskovic et al.
2009). These granitic plutons are controlled by the localized extension along the hanging-wall of previous sutures;

- The Cenozoic Andean evolution was dominated by a shallowing wave of the subducted slab. The consequent migration of magmatism to the foreland induced the formation of an "inner arc", in which deep crustal melts were formed following crustal delamination and lithospheric mantle removal (Ramos 2018a). The Oligocenic upper crustal granitoids (IIlimani, Quimsa Cruz and Santa Vera Cruz plutons) related to compressional tectonics associated with the subduction slab steepening (Jiménez \& López-Velásquez 2008) were dated by Gillis et al. (2006). Their K/Ar ages vary between 28 and $23 \mathrm{Ma}$ (Evernden et al. 1977, McBride et al. 1983, Sugaki et al. 2003).

Hence, the Huayna Potosí, Zongo and Taquesi plutons are part of the Permo-Triassic magmatic event, and their petrographic facies include two mica granites, as well as quartz monzonites and granodiorites. The modal analyses of the four granitic rocks studied in this work are included in Table 1. The individual plutons usually grade between metaluminous to peraluminous, and crystal fractionation was their main differentiation mechanism (Ávila 1990). More mafic rocks, such as diorites or monzonites, are seen only as enclaves.

The Huayna Potosí batholith has an irregular shape, roughly rectangular with an E-W elongation (Fig. 3). In petrography, it varies between a granitic to granodioritic composition, where quartz, microcline and plagioclase are always the main components, making up usually more than $70 \%$ of the rock, while biotite and muscovite are also present in fair amounts. Small enclaves of diorite

Table 1. Modal analyses of samples RIB-2, 4, 5 and 11

\begin{tabular}{|c|c|c|c|c|}
\hline \multirow{2}{*}{$\begin{array}{l}\text { Pluton } \\
\text { sample }\end{array}$} & \multicolumn{2}{|c|}{ Huayna Potosí } & \multirow{2}{*}{$\begin{array}{c}\text { Kuticucho } \\
\text { RIB-5 }\end{array}$} & \multirow{2}{*}{$\begin{array}{l}\text { Taquesi } \\
\text { RIB-11 }\end{array}$} \\
\hline & RIB-2 & RIB-4 & & \\
\hline Rock & Granite & Granite & $\begin{array}{c}\text { Foliated } \\
\text { granite }\end{array}$ & Granodiorite \\
\hline Quartz & 20 & 15 & 16 & 35 \\
\hline Plagioclase & 10 & 10 & 10 & 30 \\
\hline Orthoclase & & & & 10 \\
\hline Microcline & 27 & 43 & 40 & \\
\hline Perthite & 3 & 2 & & 5 \\
\hline Biotite & 13 & 5 & 15 & 13 \\
\hline Muscovite & 20 & 10 & 8 & \\
\hline Apatite & 3 & 3 & 1 & 3 \\
\hline Zircon & & & & 1 \\
\hline Garnet & & & 3 & \\
\hline Chlorite & 1 & 5 & & \\
\hline Sericite & & 1 & 6 & \\
\hline Epidote & 1 & 1 & & \\
\hline Titanite & & & 1 & \\
\hline Tourmaline & & & & 2 \\
\hline Fe-oxides & 2 & 5 & & 1 \\
\hline Total & 100 & 100 & 100 & 100 \\
\hline
\end{tabular}


rocks are observed. Figures $4 \mathrm{~A}$ and $4 \mathrm{~B}$ are photographs taken in the field of one of Huayna Potosí batholith rocks, RIB-2. Figures 5A and 5B are microphotographs for RIB-2 and RIB-4, respectively. Textures are granular, hipidiomorphic and sometimes poikilitic. In Figure 5A, crystals of subhedral biotite and muscovite are shown along with quartz, orthoclase, and microcline. Slightly hydrothermal sericite alters the K-feldspars. In Figure 5B, subhedral muscovite and minor biotite are shown along with quartz. Garnet may be present in some samples, and apatite, zircon, titanite, and Fe-oxides are the main accessory minerals.
The Zongo pluton is essentially a granite with two micas and presents a mineralogical composition like the Huayna Potosi. As shown in Figure 3, this pluton seems to be located within two NW strike reverse fault systems with vergence to the SW, and it has been cut intensely by at least one set of faults with the same features. Two petrographic facies are found in the Zongo pluton: the foliated Kuticucho facies, which displays a moderate to strong macroscopic foliation affecting K-feldspars, quartz, and micas (see fieldwork photographs in Figs. 4C and 4D), and the Sainani microgranular facies to the $\mathrm{NE}$ (McBride et al. 1987, and references therein). Figure 5C is a microphotograph of RIB-5, in which sigmoidal and foliated
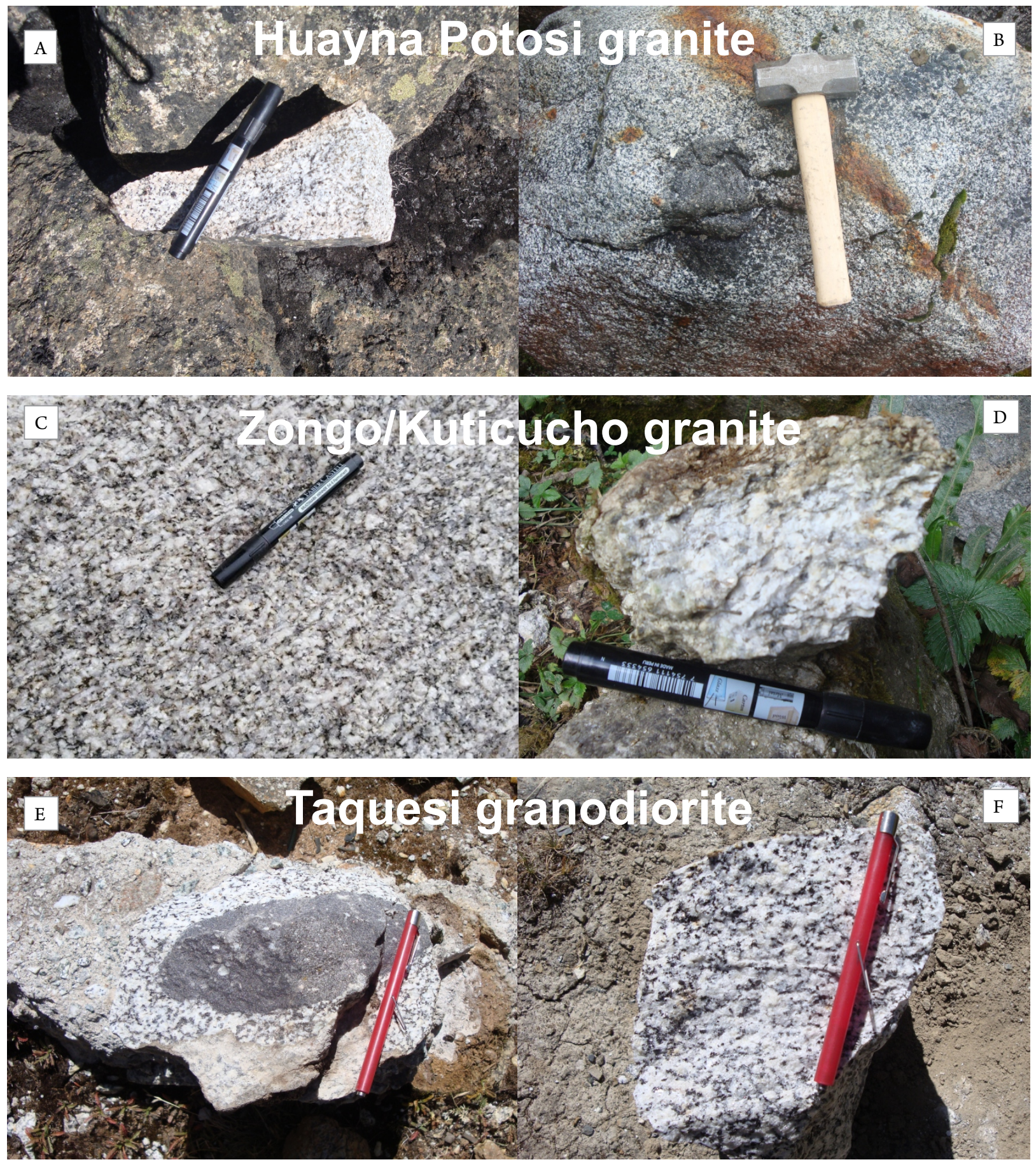

Figure 4. Field photographs: Huayna Potosí, Zongo and Taquesi plutons. (A) Two-mica granite at the SW margin of the Huayna Potosi pluton. (B) Dioritic enclave of the Huayna Potosi pluton. (C) Equigranular, slightly foliated granitic sample of the Zongo pluton. (D) Foliated Zongo granite, Kuticucho facies. (E) Small dioritic inclusion of the Taquesi pluton. (F) Granodiorite, southern margin of the Taquesi pluton. 
muscovite is shown sheared with ondulatory quartz and deformed plagioclase.

The Taquesi pluton has an ellipsoidal shape, with a length of $15 \mathrm{~km}$ along its major axis, parallel to the NW-SE strike of the major Andean structures. It is composed mostly of a granular to microgranular biotite granodiorite (Figs. 4E and 4F) with quartz, plagioclase, $\mathrm{k}$-feldspar, biotite, apatite, and Fe-oxides. Figure 5D is a microphotograph, in which subhedral biotite flakes are shown along with quartz and plagioclase. At its southern border, enclaves of hornfels from the country rock can be found, reaching sometimes almost $10 \mathrm{~cm}$ of length.

A few mineral occurrences were mined in the past, such as the Milluni mine at the southern contact of the Huayna Potosi pluton, composed by several veins bearing a $\mathrm{Sn}-\mathrm{W}-\mathrm{Zn}$ mineralization, cutting the Silurian slates of Catavi Formation (Ahlfeld \& Schneider-Scherbina 1964). Moreover, the Chojlla Mine is located about $8 \mathrm{~km}$ east of the Taquesi pluton within a mineralized greisen $(\mathrm{Sn}-\mathrm{W})$, which was interpreted by the same authors as a small part of a cupula intruding the sedimentary roof at the top of this pluton.

\section{ANALYTICAL METHODS}

In this paper, the geochronological and isotopic data already available in literature will be discussed and reinterpreted in order to evaluate the geological history of the studied region. K-Ar and $\mathrm{U} / \mathrm{Pb}$ age dating can be found in the papers of Evernden $e t$ al. (1977), McBride et al. (1983, 1987), Kennan et al. (1995), Farrar et al. (1990) and Gillis et al. (2006). Description of the analytical methods used by these authors shall be looked after in the respective references. For the ages obtained in 1978 at the São Paulo laboratory (Cordani et al. 1980), the employed methods can be referred as follows:

- The techniques employed for the K-Ar analyses were those described by Amaral et al. (1966). The only difference is that a calibrated pipette was used for the addition of the ${ }^{38} \mathrm{Ar}$ tracer. Potassium content was measured by means of a flame photometer, with a normal error of about $1 \%$ or less. Argon extraction was made by means of an induction heater, and the isotopic ratios were determined in a Nuclide Reynolds-type instrument made of Pyrex glass. Average error of the analyses was around $2 \%$ for measurements with less than $90 \%$ of atmospheric correction;

- The techniques employed for the $\mathrm{Rb}-\mathrm{Sr}$ method were described by Cordani \& Iyer (1979). Total Rb and Sr contents were measured using X-ray fluorescence, and the $\mathrm{Sr}$ isotopic measurements were carried out in the Varian TH-5 solid-source mass spectrometer of the São Paulo laboratory, with a chart recorder output, and the isotopic ratios were determined by directly measuring the peak heights.
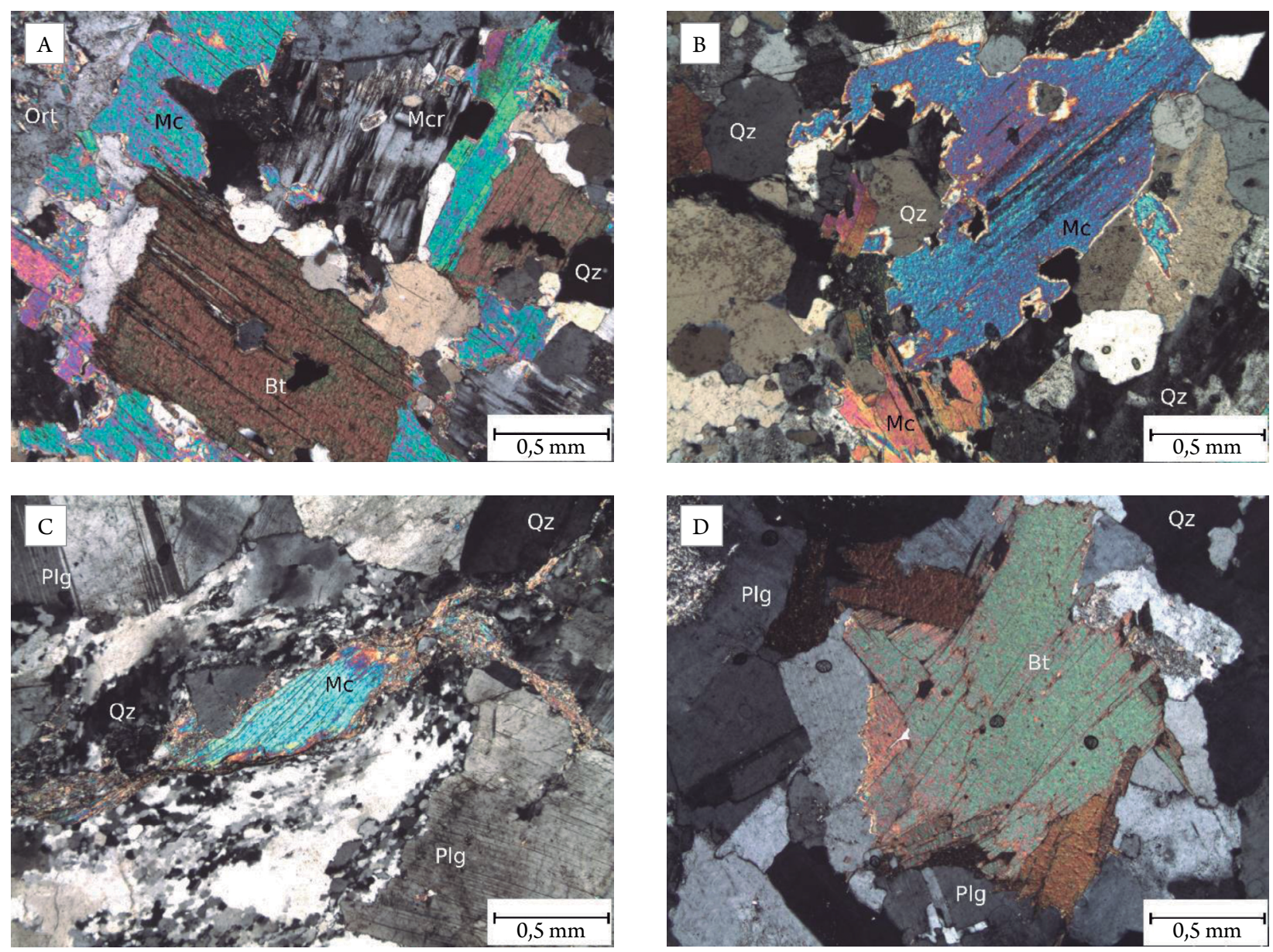

Bt: biotite; Mc: muscovite; Plg: plagioclase; Qz: quartz; Ort: orthoclase; Mcr: microcline.

Figure 5. Microphotographs: Huayna Potosí, Zongo and Taquesi plutons. The granites of Huayna Potosí and the granodiorite of Taquesi have hipidiomorfic textures, meanwhile the Zongo/Kuticuho granite has a foliated structure. (A) and (B) respectively, samples RIB-2 and RIB-4, for the Huayna Potosí granite. (C) Sample RIB-5 of the foliated Zongo/Kuticucho granite. (D) Sample RIB-11 of the Taquesi granodiorite. 
The ${ }^{87} \mathrm{Sr} /{ }^{86} \mathrm{Sr}$ values were normalized to the 0.1194 value, and the Eimer \& Amend Sr standard run concurrently yielded a ${ }^{87} \mathrm{Sr} /{ }^{86} \mathrm{Sr}$ value of $0.7082 \pm 0.0013$ ( 1 sigma). Regression analyses of the $\mathrm{Rb} / \mathrm{Sr}$ data were carried out using the method of York (1968). Based on laboratory experimental data, the ${ }^{87} \mathrm{Rb} /{ }^{86} \mathrm{Sr}$ and ${ }^{87} \mathrm{Sr} /{ }^{86} \mathrm{Sr}$ relative standard deviations were assumed at $2.8 \%$ and $10^{-3}$, respectively.

For the $\mathrm{U} / \mathrm{Pb}$ SHRIMP analyses on single zircon crystals made recently for this paper, the SHRIMP II of the São Paulo laboratory at USP was employed and the procedures, based on Williams (1998), are described by Sato et al. (2014). Uranium abundance and $\mathrm{U} / \mathrm{Pb}$ ratios were calibrated against the Z6266 and Temora 2 standards, and the individual ages were determined from five successive scans of the mass spectrum. Pooled ages calculated herein are weighted mean ${ }^{206} \mathrm{~Pb} /{ }^{238} \mathrm{U}$ dates (one sigma level, rounded to the nearest million year). Age values in tables and figures are given with one sigma precision, and the average ages reported in the text are weighted-mean ${ }^{207} \mathrm{~Pb} /{ }^{206} \mathrm{~Pb}$ ages, with $95 \%$ confidence limits. Correction for common $\mathrm{Pb}$ was made based on the measured ${ }^{204} \mathrm{~Pb}$ and the typical error component for the ${ }^{206} \mathrm{~Pb} /{ }^{238} \mathrm{U}$ ratios was lower than $2 \%$. Data were reduced by using SQUID software (Berkeley Geochronology Center), and the Concordia diagrams were prepared by using Isoplot/ Excel (Ludwig 2003). U and Th contents, isotopic ratios and ages are shown in Table 2 (A to D). The analytical data were used to prepare the Concordia diagrams shown later.

\section{GEOCHRONOLOGICAL RESULTS}

\section{$\mathrm{Rb} / \mathrm{Sr}$ and $\mathrm{K} / \mathrm{Ar}$ ages on the samples collected in 1978}

During the field excursion mentioned in the introduction, organized in 1978 by geologists from the geological service of Bolivia, GEOBOL, La Paz, made along the Zongo River, under the leadership of Guillermo Cortez Arce and with the participation of UGC, few rock samples were collected from a few outcrops of the Paleozoic metasedimentary country rocks, the Huayna Potosi and the Zongo plutons. A few of these rocks were studied, and several $\mathrm{Rb} / \mathrm{Sr}$ and $\mathrm{K} / \mathrm{Ar}$ ages were obtained at the São Paulo Geochronology Laboratory. Tables 3 and 4 report the analytical data of the samples that were dated, and Figure 3 indicates the location of the collected samples.

Samples BO-4, 5, 6 and 7 were collected from the metapelitic sediments that form the country rocks of the SW edge of the Huayna Potosi pluton. They are all very low-grade metasedimentary rocks that can be generically called as "shales" or "slates" and are related to the early Paleozoic retro-arc basin of the Famatinian orogeny. BO-4 and BO-5, collected near the Milluni Mine, and BO-7, close to the contact with the Huayna Potosi granite, can possibly be related to the Ordovician Amutara Formation. However, sample BO-6 was collected very close to a tillitic outcrop and was indicated as belonging to the Silurian Cancañiri Formation. Samples BO-9, 10 and 11 were collected within the Huayna Potosi pluton, a typical equigranular granite with millimetric minerals, where K-feldspars predominate. Biotite is ubiquitous, but muscovite is also present, especially in the BO-11 sample. Xenoliths of more mafic rocks were observed, as well as aplites and pegmatitic zones, especially in samples BO-9 and BO-10. Samples BO-12, 13 and 14 were taken from the Kuticucho facies of the Zongo pluton, where the granitic rock presents two-micas and is clearly deformed, with a strong NW-SE orientation. Finally, samples BO-16 and 17 came from the Sainani facies of the same Zongo pluton, with a similar mineralogy, but much less deformation.

Table 3 reports the analytical data of $15 \mathrm{Rb}$-Sr measurements. Four of them (BO-4, 5, 6 and 7) were made in the whole rock samples of the metapelitic Paleozoic country rocks. Five others were made from the outcrop BO-9 (A, C, D, H and I) of the Huayna Potosi pluton, near its southern border. The remaining six ones were made from outcrops of the Zongo pluton, five of which as whole rock samples (BO-12B, 13A, 14A, 14B and 17A) and one from a concentrate of K-feldspars of outcrop $\mathrm{BO}-13$. Figure 6 is a $\mathrm{Rb} / \mathrm{Sr}$ regression diagram that reports all the analytical points included in Table 3 . The three groupings of samples, Paleozoic metasedimentary rocks, Huayna Potosi granite and Zongo granite, clearly occupy distinct places in Figure 6, thus, they had been subjected to different geological histories. The analytical points of the Paleozoic slates, BO-4, 5, 6 and 7, although not well aligned in the isochron diagram, present a reasonable tendency close to a least squares straight line that could correspond to a $\mathrm{Rb} / \mathrm{Sr}$ "errorchron" with a $344 \pm 38 \mathrm{Ma}$ age and a ${ }^{87} \mathrm{Sr} /{ }^{86} \mathrm{Sr}$ initial ratio of about $0.720 \pm 0.004$. The five granitic rock samples collected from the same BO-9 outcrop shall be considered cogenetic and showed a better alignment along a least square straight line, which could possibly correspond to a $\mathrm{Rb} / \mathrm{Sr}$ isochron with a $224 \pm 28 \mathrm{Ma}$ age and $\mathrm{a}^{87} \mathrm{Sr} /{ }^{86} \mathrm{Sr}$ initial ratio of about 0.7103 \pm 0.0016 . Moreover, the four analytical points for the Zongo granitic rocks, BO-13A, 14A, 14B and 17A, cluster quite close to one-another in the diagram, and three of them seem to be reasonably aligned. Such fact indicates a tendency corresponding to a $\mathrm{Rb} / \mathrm{Sr}$ "errorchron" with a $186 \pm 25 \mathrm{Ma}$ age and a very high ${ }^{87} \mathrm{Sr} /{ }^{86} \mathrm{Sr}$ initial ratio of about $0.731 \pm 0.008$.

Table 4 includes analytical data of $12 \mathrm{~K}$-Ar measurements made in separated minerals or in whole-rock samples. There was no grouping within the set of age values; therefore, each rock sample had a proper and distinct thermal evolution, leading to an argon loss with a different proportion. Two samples from the regional slates, one of them analyzed in duplicate, yielded different K-Ar ages, all of them much younger than the age values attributed to early Paleozoic rocks. The K-Ar obtained from micas of the Huayna Potosi and Zongo plutons were also very different, the oldest of which was a biotite from granite $\mathrm{BO}-10$ with $209 \mathrm{Ma}$ and the youngest was the K-feldspar apparent age of sample BO-13A, with $63 \mathrm{Ma}$.

\section{New U-Pb SHRIMP zircon ages}

Four granitoid samples were recently collected by one of the authors, and their locations are indicated in Figure 3. The first two (RIB-2 and RIB-4), from the Huayna Potosi pluton, are light-grey two-mica granites (Fig. 4A) characterized 
Braz. J. Geol. (2019), 49(2): e20190016

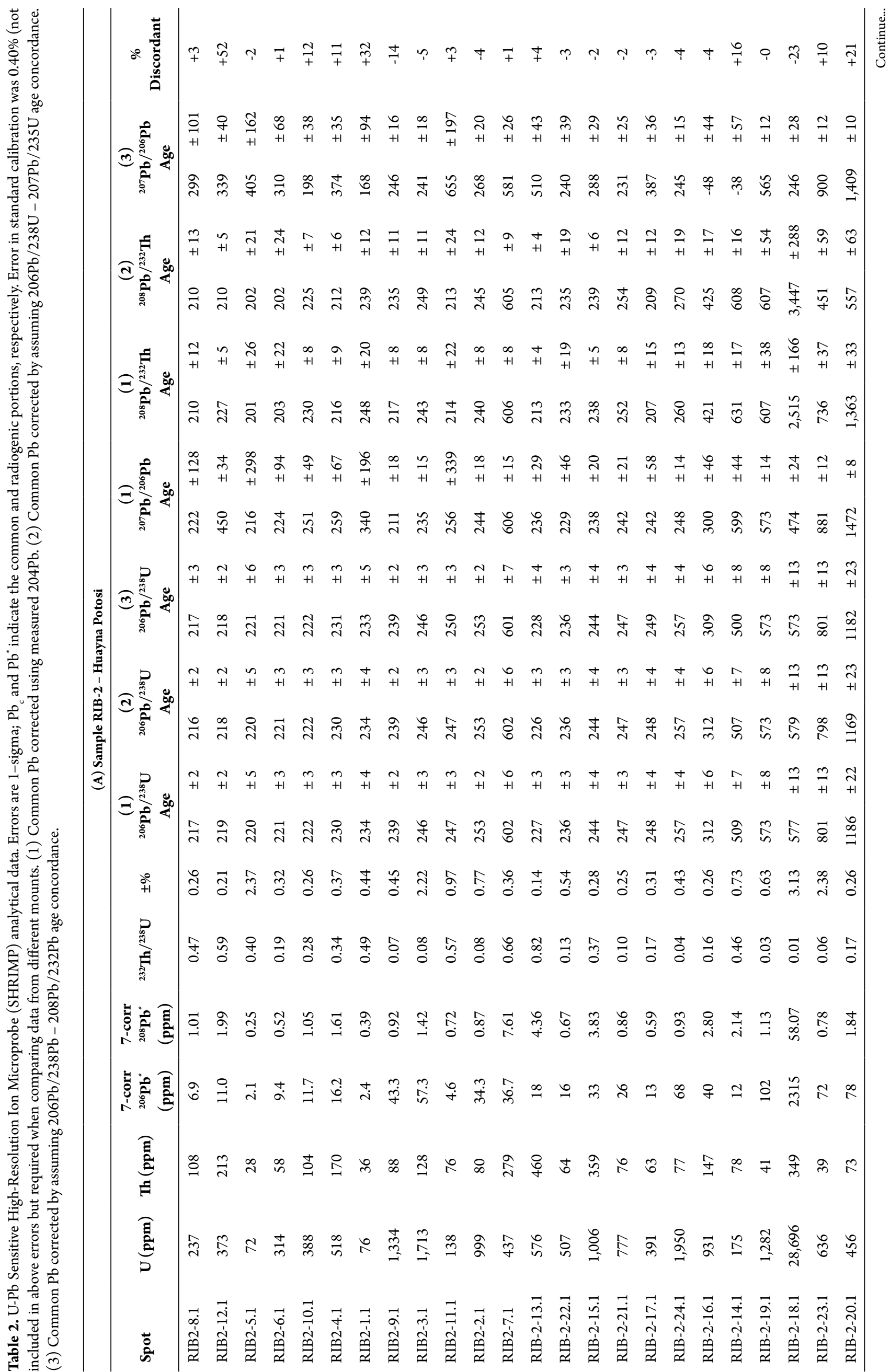




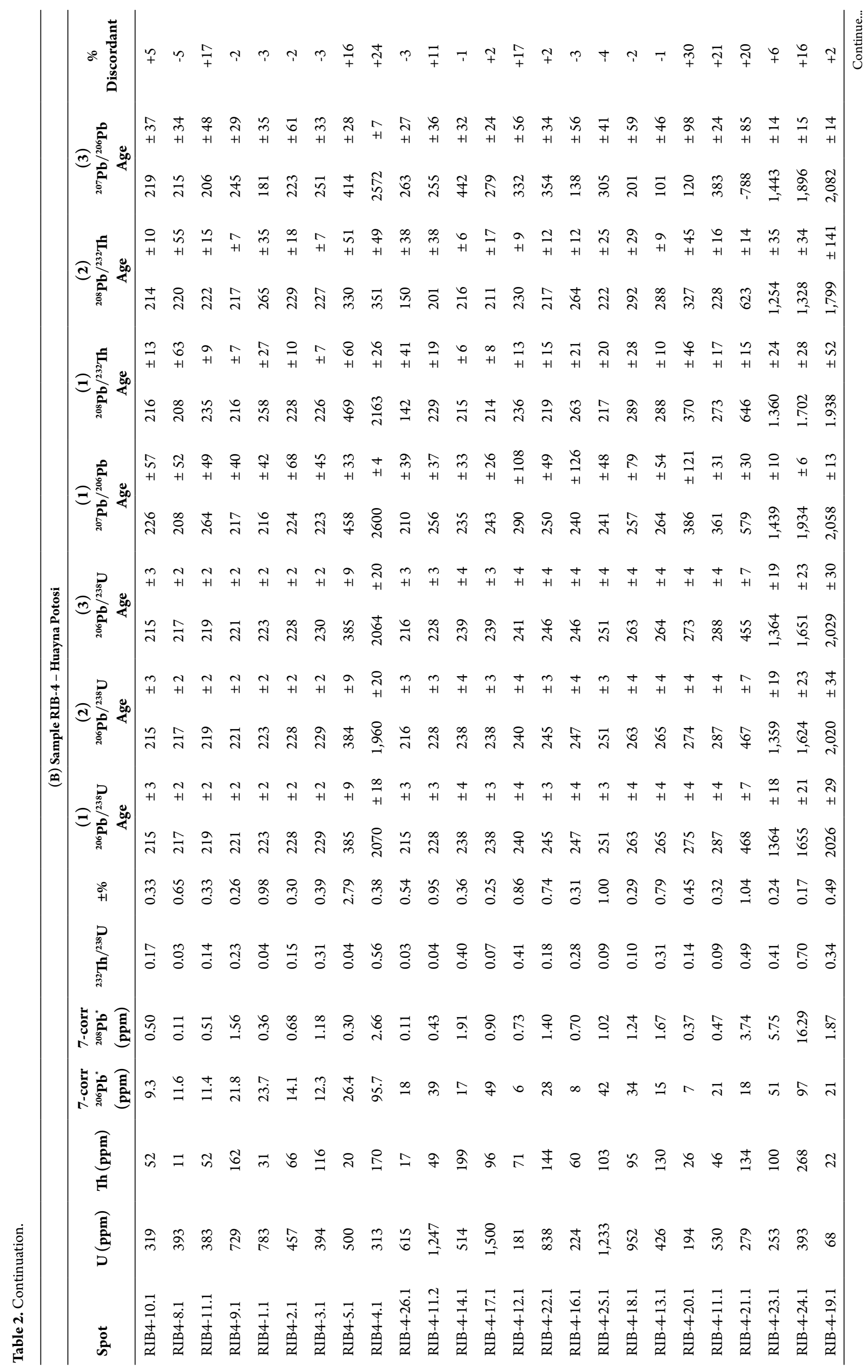


Braz. J. Geol. (2019), 49(2): e20190016

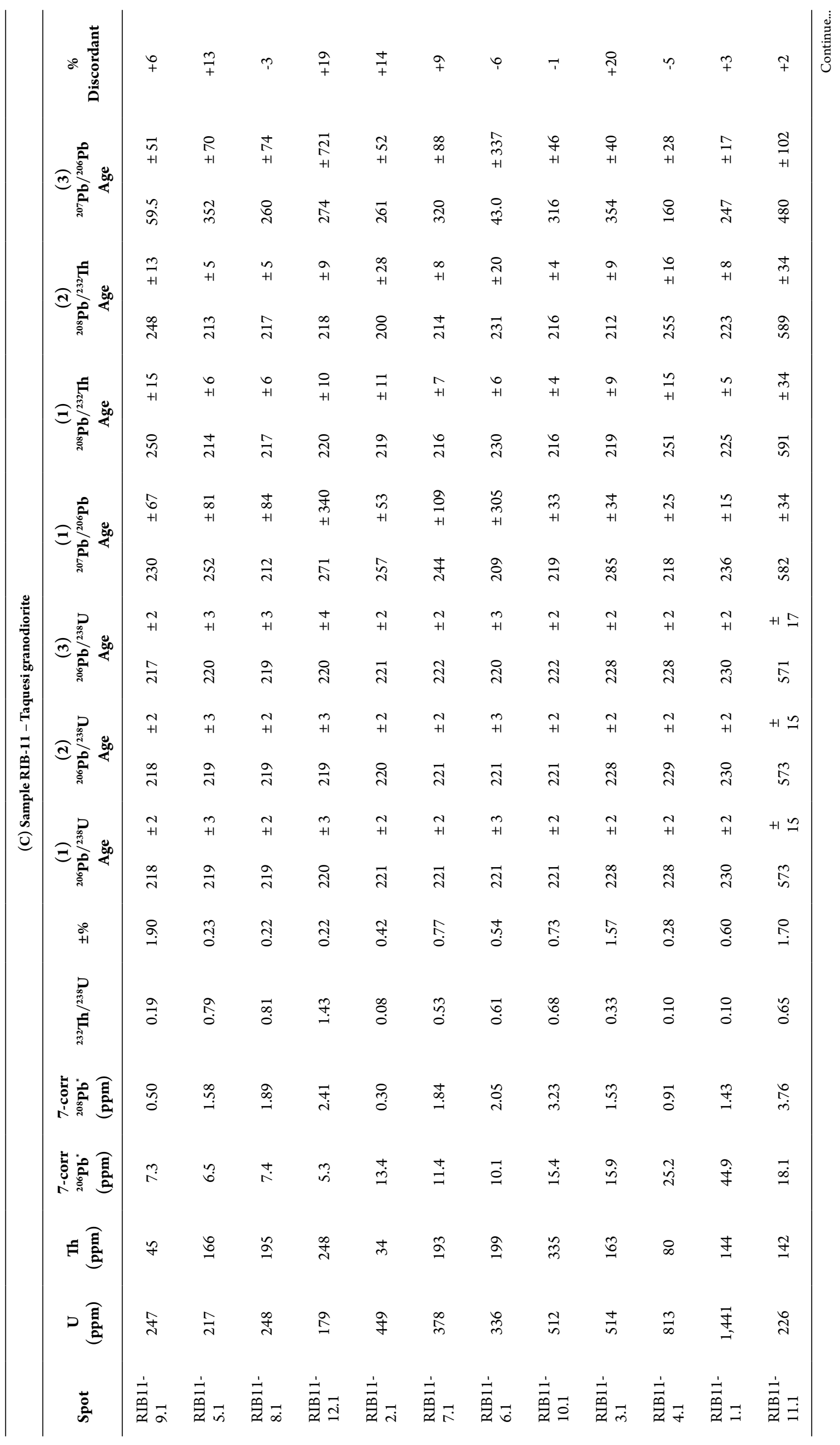




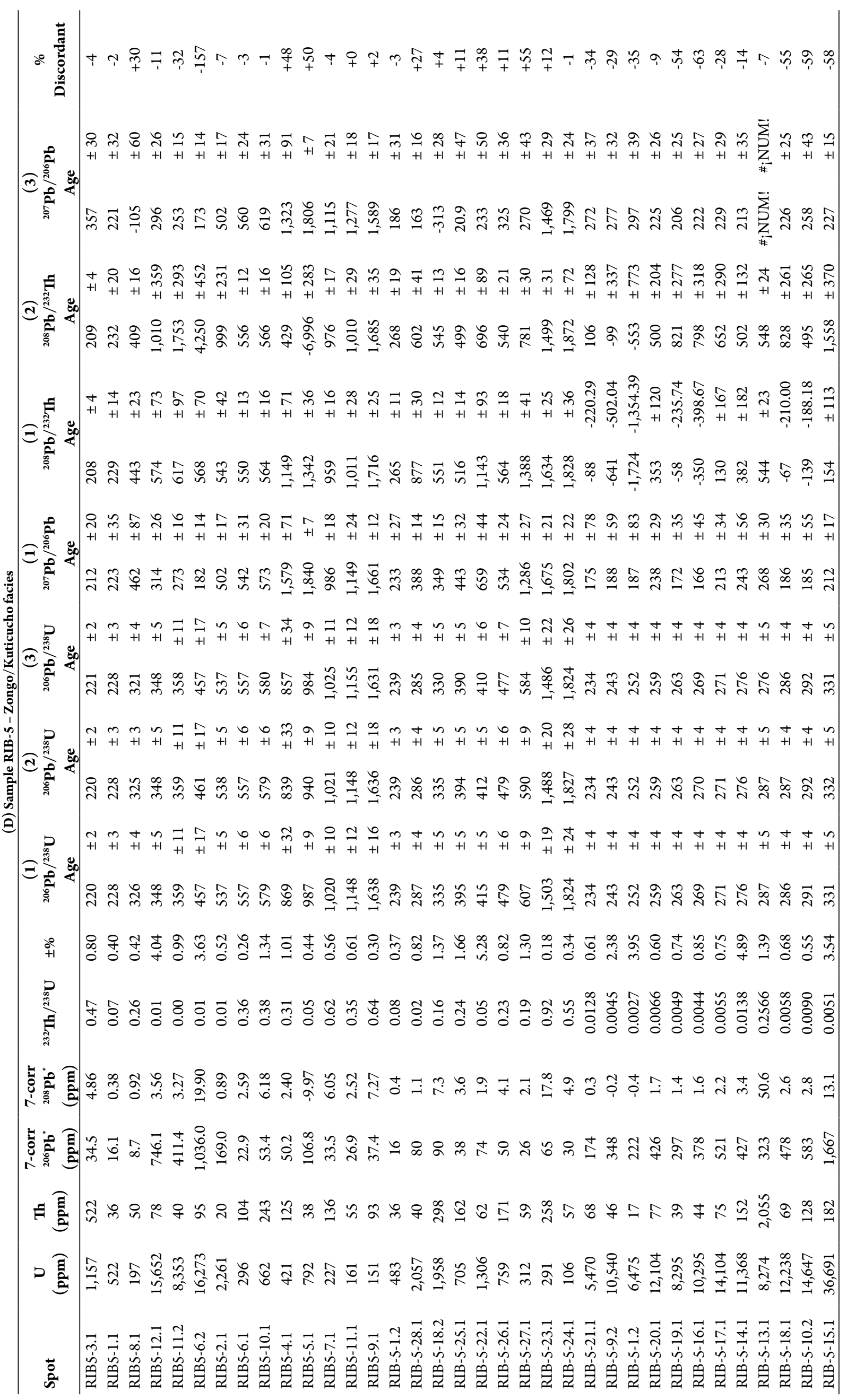


by a massive equigranular millimetric texture made of quartz, microcline, plagioclase, biotite, and muscovite. Sample RIB5, from the Zongo/Kuticucho foliated pluton, is also a twomica granite, with similar mineralogy, but presenting large centimetric crystals of K-feldspar, some accessory garnet, and a strong NW-SE foliation (Fig. 4D). Sample RIB-11, from the Taquesi pluton, is a massive equigranular granodiorite (Fig. 4F), in which plagioclase predominates over K-feldspar.

Table 3. Rb-Sr analytical data acquired in 1978 at the Geochronology Laboratory of the Universidade de São Paulo.

\begin{tabular}{|c|c|c|c|c|c|c|c|c|c|c|c|c|c|}
\hline Locality & $\begin{array}{c}\text { Longitude } \\
\text { S }\end{array}$ & $\begin{array}{c}\text { Latitude } \\
\text { W }\end{array}$ & Sample & Material & Rock & $\begin{array}{c}\mathbf{R b} \\
(\mathbf{p p m})\end{array}$ & $\begin{array}{c}\text { Sr } \\
(\mathbf{p p m})\end{array}$ & ${ }^{87} \mathbf{R b} /{ }^{86} \mathrm{Sr}$ & Error & ${ }^{87} \mathrm{Sr} /{ }^{86} \mathrm{Sr}$ & Error & $\begin{array}{c}\text { Age } \\
(1.42)\end{array}$ & Error \\
\hline Milluni & $16^{\circ} 19^{\prime} 35^{\prime \prime}$ & $68^{\circ} 9^{\prime} 0.58^{\prime \prime}$ & BO-4 & WR & $S$ & 241.7 & 78.8 & 8.93 & 0.18 & 0.761 & 0.0017 & 440.8 & 24.2 \\
\hline Milluni & $16^{\circ} 18^{\prime} 46^{\prime \prime}$ & $68^{\circ} 8^{\prime} 10.4^{\prime \prime}$ & BO-5 & WR & $S$ & 161.9 & 58.9 & 8 & 0.16 & 0.7604 & 0.0009 & 486.2 & 23.5 \\
\hline Milluni & $16^{\circ} 18^{\prime} 9{ }^{\prime \prime 2}$ & $68^{\circ} 7^{\prime} 51.8^{\prime \prime}$ & BO-6 & WR & $S$ & 135.8 & 101.8 & 3.87 & 0.08 & 0.7383 & 0.0014 & 602.6 & 46.7 \\
\hline Milluni & $16^{\circ} 17^{\prime} 52^{\prime \prime}$ & $68^{\circ} 7^{\prime} 47.1^{\prime \prime}$ & BO-7 & WR & $S$ & 141.6 & 203.1 & 2.02 & 0.04 & 0.7302 & 0.0017 & 873.4 & 94.3 \\
\hline $\mathrm{HP}$ & $16^{\circ} 17^{\prime} 21^{\prime \prime}$ & $68^{\circ} 7^{\prime} 45.8^{\prime \prime}$ & BO-9A & WR & G & 133.1 & 315.9 & 1.22 & 0.02 & 0.7134 & 0.0015 & 483.3 & 144.8 \\
\hline HP & $16^{\circ} 17^{\prime} 21$ " & $68^{\circ} 7^{\prime} 45.8^{\prime \prime}$ & BO-9C & WR & G & 127.2 & 356.8 & 1.03 & 0.02 & 0.7137 & 0.001 & 590.9 & 153.4 \\
\hline $\mathrm{HP}$ & $16^{\circ} 17^{\prime} 21^{\prime \prime}$ & $68^{\circ} 7^{\prime} 45.8^{\prime \prime}$ & BO-9D & WR & G & 152.9 & 297.4 & 1.49 & 0.03 & 0.7153 & 0.0014 & 485.3 & 116.3 \\
\hline $\mathrm{HP}$ & $16^{\circ} 17^{\prime} 21^{\prime \prime}$ & $68^{\circ} 7^{\prime} 45.8^{\prime \prime}$ & BO-9I & WR & G & 249.9 & 147.2 & 4.92 & 0.1 & 0.7266 & 0.0018 & 307.8 & 39.7 \\
\hline $\mathrm{HP}$ & $16^{\circ} 17^{\prime} 21^{\prime \prime}$ & $68^{\circ} 7^{\prime} 45.8^{\prime \prime}$ & BO-9H & WR & G & 223.5 & 56.8 & 11.43 & 0.23 & 0.7464 & 0.0019 & 254.7 & 18.6 \\
\hline$S$ & $16^{\circ} 7^{\prime} 15^{\prime \prime} 9$ & $68^{\circ} 5^{\prime} 2.85^{\prime \prime}$ & BO-17A & WR & G & 383.9 & 80.3 & 13.92 & 0.28 & 0.7722 & 0.0011 & 339.1 & 15 \\
\hline $\mathrm{K}$ & $16^{\circ} 8^{\prime} 0^{\prime \prime} 76$ & $68^{\circ} 6^{\prime} 44.2^{\prime \prime}$ & BO-14A & WR & G & 397.7 & 71.9 & 16.11 & 0.32 & 0.7741 & 0.0011 & 301.2 & 13.1 \\
\hline $\mathrm{K}$ & $16^{\circ} 8^{\prime} 0^{\prime \prime} 76$ & $68^{\circ} 6^{\prime} 44.2^{\prime \prime}$ & BO-14B & WR & G & 373.4 & 55.6 & 19.58 & 0.39 & 0.7831 & 0.0012 & 280.5 & 11.5 \\
\hline K & $16^{\circ} 9^{\prime} 20^{\prime \prime} 3$ & $68^{\circ} 7^{\prime} 9.89^{\prime \prime}$ & BO-13A & WR & G & 427.9 & 42.2 & 28.306 & 0.672 & 0.8069 & 0.0011 & 253.1 & 8.3 \\
\hline $\mathrm{K}$ & $16^{\circ} 9^{\prime} 20^{\prime \prime 2}$ & $68^{\circ} 7^{\prime} 13.1^{\prime \prime}$ & BO-12B & WR & G & 447.9 & 52.5 & 24.91 & 0.49 & 0.7967 & 0.0012 & 258.8 & 9.9 \\
\hline K & $16^{\circ} 90^{\prime \prime} 3$ & 68'7'9.89"' & BO-13A & $\mathrm{F}$ & G & 214 & 45 & 14.533 & 0.372 & 0.7809 & 0.0021 & 366.7 & 16.8 \\
\hline
\end{tabular}

HP: Huayna Potosí; K: Zongo pluton facies Kuticucho; S: Zongo pluton facies Sainani; M: muscovite; B: biotite; F: feldspar; WR: whole rocks; G: granite; Gd: granodiorite; Sh: shale; S: slates.

Table 4. K-Ar analytical data acquired in 1978 at the Geochronology Laboratory of the Universidade de São Paulo.

\begin{tabular}{|c|c|c|c|c|c|c|c|c|c|c|c|}
\hline Locality & Sample & $\begin{array}{c}\text { Longitude } \\
\text { W }\end{array}$ & $\begin{array}{l}\text { Latitude } \\
\qquad S\end{array}$ & Rock & Material & $\% \mathrm{~K}$ & $75 \% \mathrm{~K}$ & $A r^{40}$ Rad & Atm & $\begin{array}{l}\text { Age } \\
(\mathbf{M a})\end{array}$ & $\begin{array}{l}\text { Error } \\
\text { (Ma) }\end{array}$ \\
\hline Milluni & $\mathrm{BO}-4$ & $68^{\circ} 9^{\prime} 0.58$ & $16^{\circ} 19^{\prime} 35$ & $\mathrm{Sh}$ & WR & 3.750 & 0.552 & $3.704 \times 10^{-4}$ & 14.6 & 237.86 & 3.9 \\
\hline Milluni & $\mathrm{BO}-4(=4169)$ & $68^{\circ} 9^{\prime} 0.58$ & $16^{\circ} 19^{\prime} 35$ & Sh & WR & 3.750 & 0.552 & $3.705 \times 10^{-4}$ & 8.29 & 249.5 & 3.06 \\
\hline Milluni & $\mathrm{BO}-4$ & $68^{\circ} 9^{\prime} 0.58$ & $16^{\circ} 19^{\prime} 35$ & $\mathrm{Sh}$ & WR & 3.939 & 0.500 & $3.704 \times 10^{-4}$ & 14.6 & 227.13 & 3.69 \\
\hline Milluni & $\mathrm{BO}-5$ & $68^{\circ} 8^{\prime} 10.4$ & $16^{\circ} 18^{\prime} 46$ & S & WR & 2.537 & 0.500 & $3.704 \times 10^{-4}$ & 5.26 & 314.25 & 3.99 \\
\hline $\mathrm{HP}$ & BO-10 & $68^{\circ} 7^{\prime} 30.1$ & $16^{\circ} 17^{\prime} 11$ & G & B & 4.254 & 0.500 & $3.660 \times 10^{-4}$ & 56.49 & 208.94 & 3.67 \\
\hline $\mathrm{HP}$ & BO-10 & $68^{\circ} 7^{\prime} 30.1$ & $16^{\circ} 17^{\prime} 11$ & G & B & 4.459 & 0.500 & $3.660 \times 10^{-4}$ & 56.49 & 199.82 & 3.51 \\
\hline $\mathrm{HP}$ & $\mathrm{BO}-9 \mathrm{~A}$ & $68^{\circ} 7^{\prime} 47.3$ & $16^{\circ} 17^{\prime} 24$ & G & B & 3.262 & 1.720 & $3.704 \times 10^{-4}$ & 63.12 & 146.14 & 8.29 \\
\hline $\mathrm{HP}$ & $\mathrm{BO}-9 \mathrm{~A}$ & $68^{\circ} 7^{\prime} 47.3$ & $16^{\circ} 17^{\prime} 24$ & G & $\mathrm{B}$ & 3.118 & 1.741 & $1.925 \times 10^{-4}$ & 63.12 & 152.6 & 8.67 \\
\hline $\mathrm{HP}$ & BO-11 & $68^{\circ} 7^{\prime} 7.34$ & $16^{\circ} 16^{\prime} 53$ & G & M & 4.781 & 2.723 & $3.532 \times 10^{-4}$ & 48.97 & 181.2 & 6.63 \\
\hline $\mathrm{HP}$ & BO-11 & $68^{\circ} 7^{\prime} 7.34$ & $16^{\circ} 16^{\prime} 53$ & G & M & 5.921 & 2.165 & $3.532 \times 10^{-4}$ & 48.97 & 147.62 & 4.82 \\
\hline $\mathrm{K}$ & $\mathrm{BO}-13 \mathrm{~A}$ & $68^{\circ} 7^{\prime} 9.89$ & $16^{\circ} 9^{\prime} 20.3$ & G & $\mathrm{F}$ & 2.586 & 0.500 & $6.661 \times 10^{-4}$ & 67.9 & 65.14 & 1.56 \\
\hline $\mathrm{K}$ & $\mathrm{BO}-13 \mathrm{~A}$ & $68^{\circ} 7^{\prime} 9.89$ & $16^{\circ} 9^{\prime} 20.3$ & G & $\mathrm{F}$ & 2.691 & 0.500 & $6.661 \times 10^{-4}$ & 67.9 & 62.65 & 1.5 \\
\hline $\mathrm{K}$ & BO-13A & $68^{\circ} 7^{\prime} 9.89$ & $16^{\circ} 9^{\prime} 20.3$ & G & B & 5.924 & 0.510 & $1.854 \times 10^{-4}$ & 22.81 & 78.82 & 1.26 \\
\hline $\mathrm{K}$ & BO-13A & $68^{\circ} 7^{\prime} 9.89$ & $16^{\circ} 9^{\prime} 20.3$ & G & $\mathrm{B}$ & 6.240 & 0.672 & $1.854 \times 10^{-4}$ & 22.81 & 74.91 & 1.24 \\
\hline $\mathrm{K}$ & $\mathrm{BO}-13 \mathrm{~A}$ & $68^{\circ} 7^{\prime} 9.89$ & $16^{\circ} 9^{\prime} 20.3$ & G & B & 5.924 & 0.510 & $1.854 \times 10^{-4}$ & 22.81 & 78.82 & 1.26 \\
\hline $\mathrm{K}$ & BO-13A & $68^{\circ} 7^{\prime} 9.89$ & $16^{\circ} 9^{\prime} 20.3$ & G & M & 4.732 & 1.003 & $2.532 \times 10^{-4}$ & 27.9 & 132.8 & 3.28 \\
\hline $\mathrm{K}$ & $\mathrm{BO}-13 \mathrm{~B}$ & $68^{\circ} 7^{\prime} 9.89$ & $16^{\circ} 9^{\prime} 20.3$ & G & $\mathrm{M}$ & 7.542 & 1.484 & $5.685 \times 10^{-4}$ & 18.81 & 184.41 & 3.52 \\
\hline $\mathrm{K}$ & $\mathrm{BO}-13 \mathrm{~A}$ & $68^{\circ} 7^{\prime} 9.89$ & $16^{\circ} 9^{\prime} 20.3$ & G & $\mathrm{M}$ & 4.974 & 1.325 & $2.532 \times 10^{-4}$ & 27.9 & 126.61 & 3.32 \\
\hline$S$ & $\mathrm{BO}-17 \mathrm{~B}$ & $68^{\circ} 5^{\prime} 13.3$ & $16^{\circ} 7^{\prime} 22.4$ & G & M & 8.018 & 1.367 & $5.685 \times 10^{-4}$ & 18.81 & 173.97 & 3.17 \\
\hline$S$ & $\mathrm{BO}-17 \mathrm{~B}$ & $68^{\circ} 5^{\prime} 13.3$ & $16^{\circ} 7^{\prime} 22.4$ & G & $\mathrm{M}$ & 7.542 & 1.484 & $5.685 \times 10^{-4}$ & 18.81 & 184.41 & 3.52 \\
\hline$S$ & BO-16 & $68^{\circ} 5^{\prime} 22.4$ & $16^{\circ} 7^{\prime} 25.4$ & G & M & 8.207 & 0.500 & $4.759 \times 10^{-4}$ & 21.64 & 143.43 & 2.24 \\
\hline$S$ & $\mathrm{BO}-17 \mathrm{~A}$ & $68^{\circ} 5^{\prime} 13.3$ & $16^{\circ} 7^{\prime} 22.4$ & G & M & 6.741 & 1.581 & $2.082 \times 10^{-4}$ & 15.81 & 77.85 & 1.5 \\
\hline
\end{tabular}

HP: Huayna Potosí; K: Zongo pluton facies Kuticucho; S: Zongo pluton facies Sainani; M: muscovite; B: biotite; F: feldspar; WR: whole rocks; G: granite; Gd: granodiorite; Sh: shale; S: slates. 
The zircon crystals were extracted from these rocks in sizes between 100 and $250 \mu \mathrm{m}$ mesh, by means of a normal preparation routine, using Wilfly table, magnetic separator, and heavy liquids. About 80 grains from each sample were mounted in one epoxy cylinder (SP-362), together with a few fragments of the Temora 2 standard, and the mounts were covered by a thin layer of gold $(6-8 \mathrm{~nm})$ to assure uniform electrical conductivity during the analyses. Scanning electron microscopy (SEM) was performed to produce cathode-luminescence (CL) images before the SHRIMP work in order to select the best zircon domains for the analytical work.

Figure 7 shows the CL images of the zircon crystals from the four studied samples as they were included in mount SP-362. For samples RIB-2 and RIB-4 of the Huayna Potosí pluton (Figs. 7A and 7B), the images of the zircon crystals are quite similar, while they present several forms, shapes, and structures. Some of them have prismatic habit with lengths mostly between 50 and $200 \mu \mathrm{m}$, a few longer up to $400 \mu \mathrm{m}$, as well as many fragments. Many grains include circular or elliptical white cores, surrounded by dark edges typical of high uranium content. Moreover, igneous oscillatory zoning is present in a few grains. In the case of the zircon grains from sample RIB-11 of the Taquesi pluton (Fig. 7D), they are well formed, prismatic and quite larger $(300-600 \mu \mathrm{m}$ length) than the ones from the previous samples. Igneous oscillatory zoning is frequent; however, white cores or black rims are rare. As shown in Table 2C, the uranium content of the grains from samples RIB-2, 4 and 11 was quite typical of magmatic zircon grains, usually below 1,000 ppm and presenting an average value between 300 and $400 \mathrm{ppm}$. The Th/U ratio, generally higher than 0.2 , also corresponds to a normal igneous origin.
The numerous nuclei showing a sharp white coloration in the CL images, that were thought to be very low in uranium, presented normal-type uranium content, similarly to the domains with greyish oscillatory zones.

The CL images of sample RIB-5 from the Zongo pluton (Kuticucho facies) (Fig. 7C) are very different in zircon typology from those of the other samples. About half of the grains present a small white core associated with medium to large black edges. Within the cores, oscillatory zoned regions are not found, and in only a few zircon crystals, a faint ghost-type structure can be seen. Several grains are solid black fragments, and the black color is due to the very high uranium content, as it is evident from a quick examination of Table 2C. Moreover, there is another zircon population that shows a bulk dark matrix containing small white spots. In this paper, these crystals, probably completely metamict, were not analyzed. The small white cores of this sample presented similar uranium content as the correspondent white cores of the other three samples. However, in RIB-5, the large black domains present a very high proportion of uranium, and a somewhat different procedure had to be employed for their analyses. In order to cut the intensity of the ion beam that would hit the electrometer of the SHRIMP, it was filtered by partially closing the post-Electrostatic Analyzer slit (pESA), decreasing its intensity by a factor of 20 . The black domains shown by sample RIB-5 may have extremely high uranium content, up to 37,000 ppm (RIB-515.1 in Tab. 2C). Fragments of the Temora zircon standard with high concentration (>1,000 ppm) were chosen for normalization of the ${ }^{206} \mathrm{~Pb} /{ }^{238} \mathrm{U}$ ratios in that sample.

In the Concordia diagrams of Figures 8, 9 and 10, the samples RIB-2, 4 and 11 yielded robust Concordia ages,

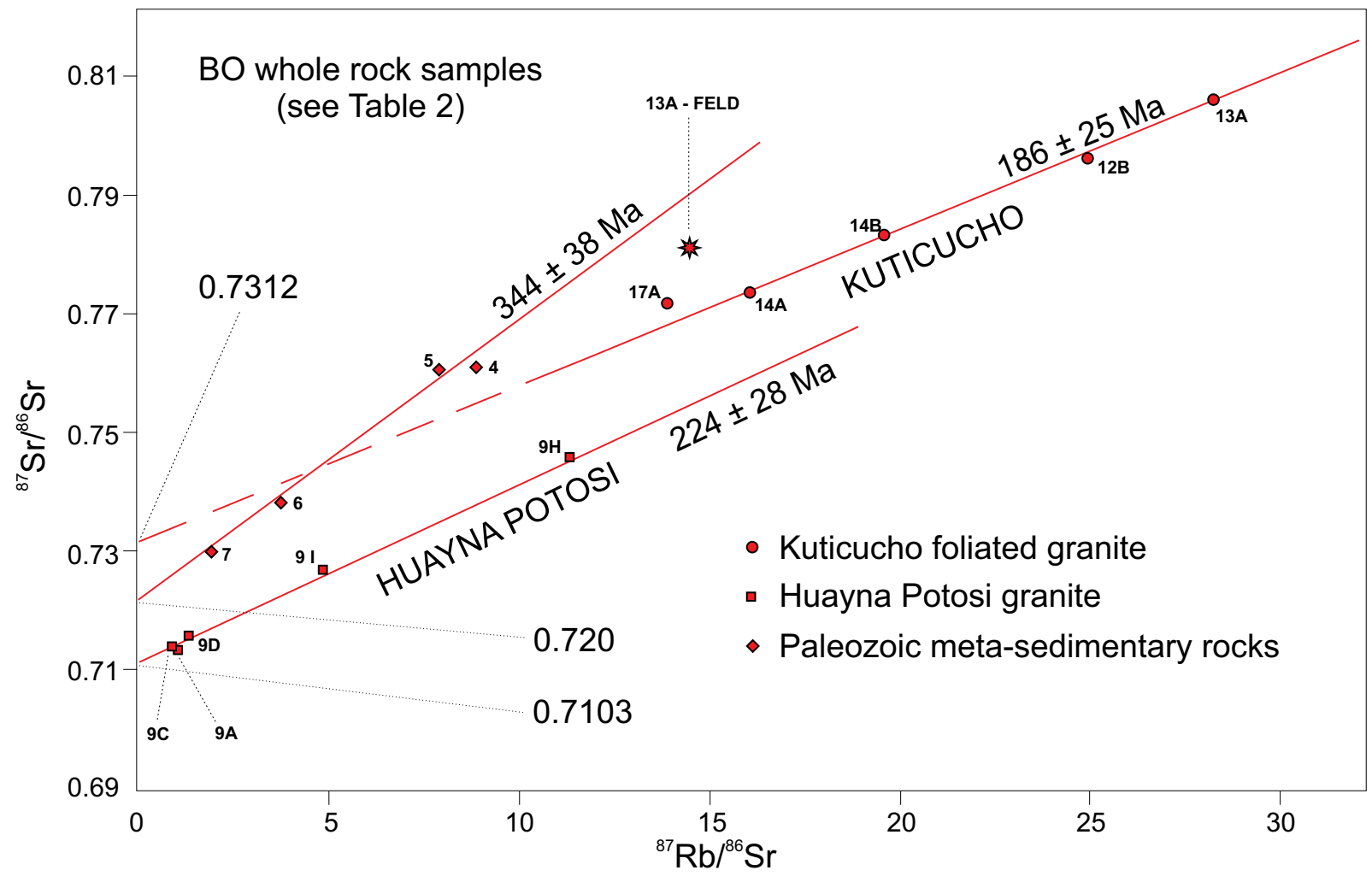

Figure 6. $\mathrm{Rb}$-Sr diagram with the best fit least squares straight lines for the Huayna Potosi and Zongo plutons and for the meta-sedimentary country rocks at the SW side. 
which represent the Triassic magmatic pulse of this part of the Cordillera Real.

For sample RIB-2 of the Huayna Potosi pluton, 24 zircon grains were dated, always within their central region, in most cases occupied by a white nucleus. Several of them presented early Paleozoic or Neoproterozoic age (Tab. 2A and Fig. 8), the oldest of which, discordant, yielded a 207/206 age of 1472 Ma. In the insert I of Figure 8, 15 zircon nuclei plotted right along the Concordia curve, covering an age interval of about $40 \mathrm{Ma}$, from about 220 to $260 \mathrm{Ma}$. All these analytical points, however, were not compatible to be included in the same calculation for a Concordia age. As depicted in inserts II and III of Figure 8, two sets compatible for such calculation were indicated: $249.2 \pm 2.5 \mathrm{Ma}$ and $222.3 \pm 2.4 \mathrm{Ma}$.

For sample RIB-4, also from the Huayna Potosi, 29 age measurements were made in 27 zircons. Like in the previous case, most of the analyses were taken in the whitish zircon cores, and several inherited grains were dated (Fig. 9). They indicate early Paleozoic, Proterozoic, and one Archean age. The rims of two of these inherited crystals were measured, yielding much younger ages and high uranium content. Like in sample RIB-2, many zircon crystals plotted right along the Concordia curve (Fig. 9I), covering an age span of $30 \mathrm{Ma}$, from 220 to $250 \mathrm{Ma}$, but also including a few analytical points located on the Concordia up to $275 \mathrm{Ma}$. Two sets compatible for a Concordia age calculation were measured, yielding $243.3 \pm 2.9 \mathrm{Ma}$ and $220.8 \pm 1.9 \mathrm{Ma}$ (Figs. 9II and 9III). The younger Concordia ages obtained for RIB-2 and RIB-4 samples are identical within error, and we consider the age of $221 \mathrm{Ma}$ to be the intrusion time of the Huayna Potosi pluton.

For sample RIB-11 of the Taquesi pluton, 12 zircon grains were analyzed, all of them presented clearly concordant ages. They form a quite homogeneous population of long prismatic crystals with oscillatory zoning, indicating magmatic crystallization. Only a small proportion of the zircon crystals have a restricted black rim. One of them, dated in its whitish core, yielded a late Proterozoic age of $573 \mathrm{Ma}$ (Tab. 2C). All the remaining 11 measurements were compatible with a calculation for a Concordia age of $221.9 \pm 1.5 \mathrm{Ma}$ (Fig. 10), which is here considered as the main crystallization episode for the Taquesi pluton.

In the case of sample RIB-5 of the Zongo pluton, 35 measurements were carried out in 28 zircon crystals. As already indicated, the zircon typology of this sample is completely
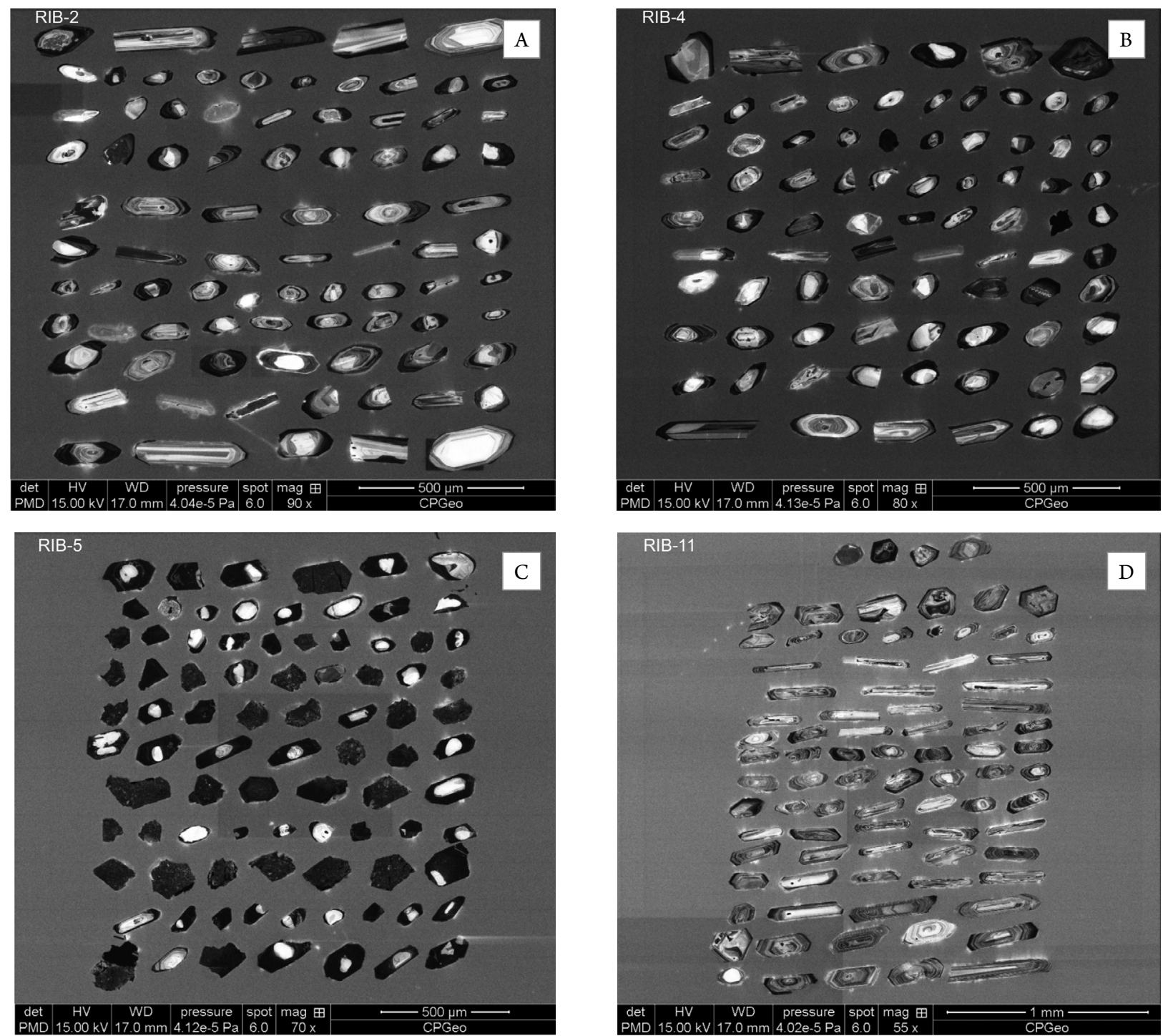

Figure 7. CL images of zircon crystals for samples RIB-2, 4, 5, and 11. (A) Sample RIB-2: Huayna Potosi. (B) Sample RIB-4: Huayna Potosi. (C) Sample RIB-5: Zongo/Kutikucho. (D) Sample RIB-11: Taquesi. 


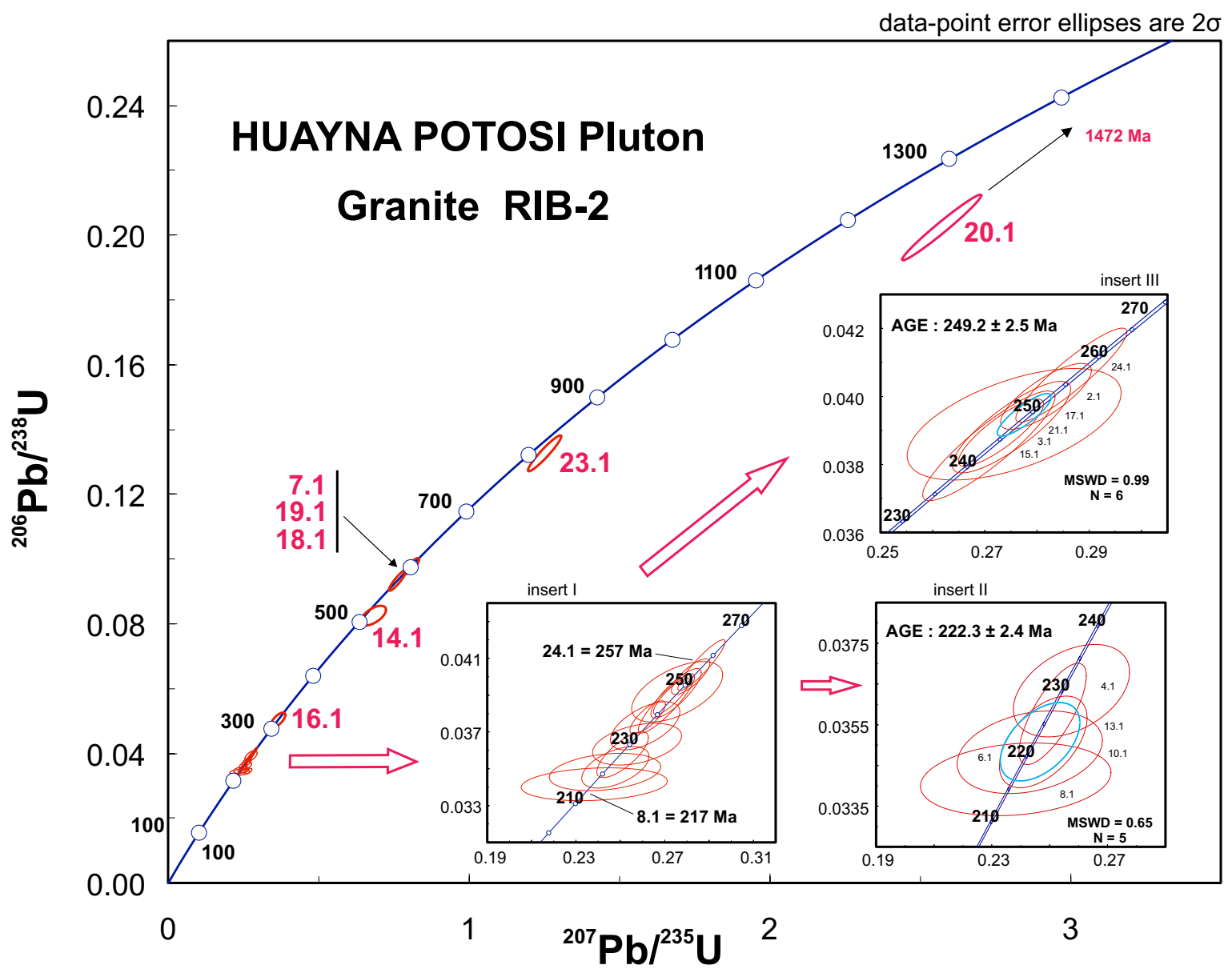

Figure 8. Concordia diagram for sample RIB-2.

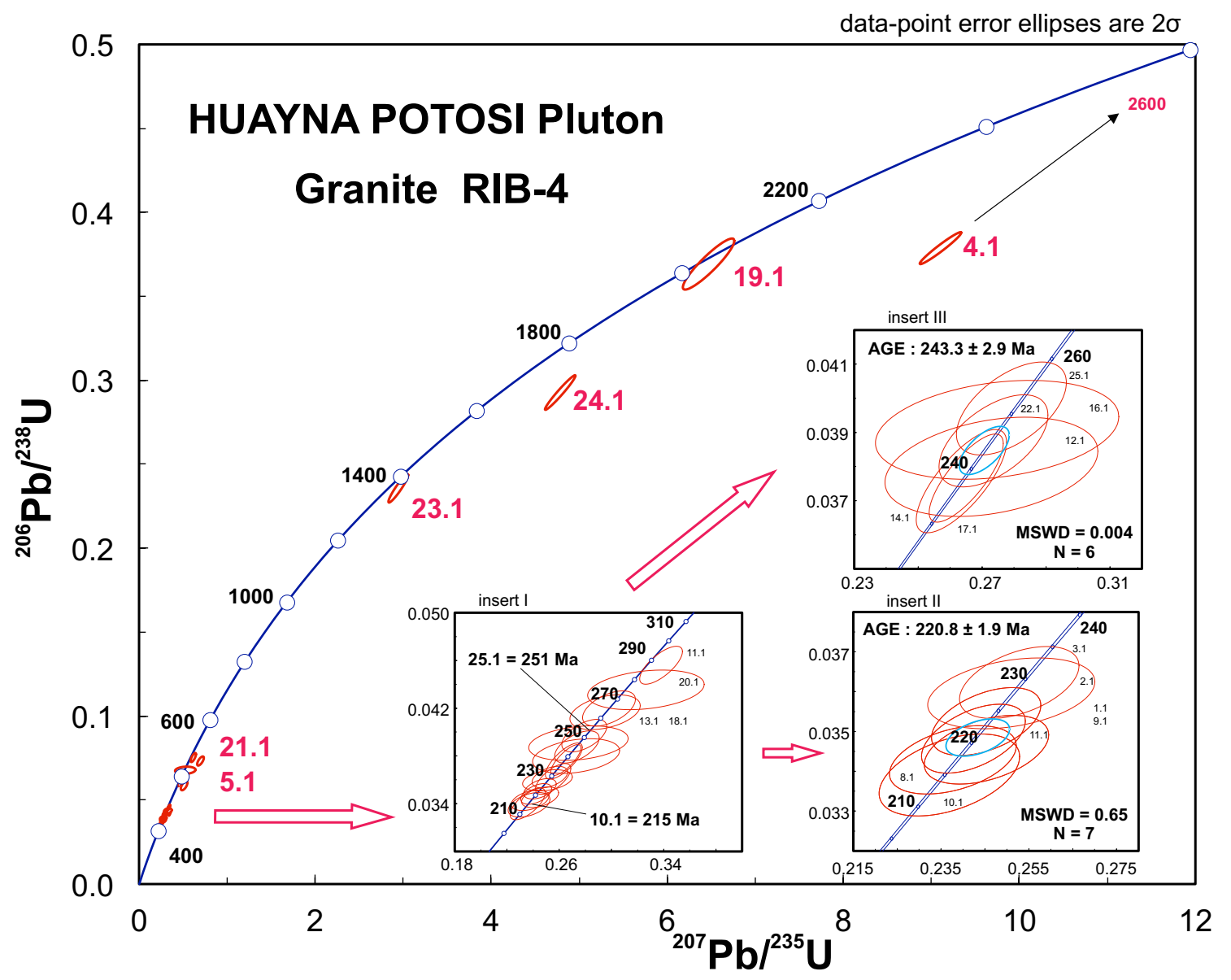

Figure 9. Concordia diagram for sample RIB-4. 
different from the previous ones. Two types of grains are present: zircon crystals with small white nuclei presenting normal uranium content, possibly always representing inherited grains, and black or dark grey spotted grains, very likely metamict, presenting high or extremely high uranium content. All the zircon images of the dated grains were shown in Figures 11 or 12. The first one is related to the measurements taken on the whitish cores and the second includes the measurements made on the black edges of the crystals.

In the Concordia diagram of Figure 11, 20 inherited zircon grains with white nuclei were plotted. Most of them yielded concordant ages, and a few other yielded normal discordant ones. Their apparent ages span the 220-1820 Ma interval. Insert I indicates a predominance of Paleozoic inherited grains. The youngest dated crystal 3.1 shows a concordant age of 221 $\mathrm{Ma}$, which is similar to the youngest ages measured for RIB-2, 4 , and 11 . We assume that most or all the dated whitish cores originate from zircon grains that were formed with primary magmatic zoning. Such original oscillatory zoning had been obliterated, probably when the black overgrowth was formed. However, despite the structural transformation, the position of the analytical point on or close to the Concordia in Figure 11 seems to indicate that the overall $\mathrm{U} / \mathrm{Pb}$ ratio of these grains was not affected.
Figure 12A shows the 15 zircon crystals in which the age measurements were made on the black domains with extreme uranium content. Figures $12 \mathrm{~B}$ and $12 \mathrm{C}$ present a normal Concordia and a Tera-Wasserburg diagram, in which all measurements have a reverse discordance mode, a situation that happens when the calculated $\mathrm{U} / \mathrm{Pb} 206 / 238$ age is older than $207 / 206$. The Tera-Wasserburg diagram, where all the analytical points plot to the left of the curve, in such reverse discordance mode, is especially clear. In both diagrams, a fair alignment of the analytical points, possibly corresponding to a linear correlation, allowed us to make regression calculations to intercept the Concordia curve. The age results were, in the first case, $222 \pm 20 \mathrm{Ma}$ and $219 \pm 21 \mathrm{Ma}$, in the second one. Although they are not very precise, these calculated ages came out similar to the ones obtained in Figures 8, 9 and 10, as representing the intrusion time of the Huayna Potosi and Taquesi plutons.

The extreme uranium concentration in the zircon crystals occurred during the final period of the petrogenetic process, when the black overgrowths were most likely formed from residual magmatic fluids. The synchronicity of the youngest measured crystallization ages encountered for the Huayna Potosi, Zongo and Taquesi plutons is remarkable, and therefore a common regional event could have been responsible for the generation of these granitoids. The final magmatic

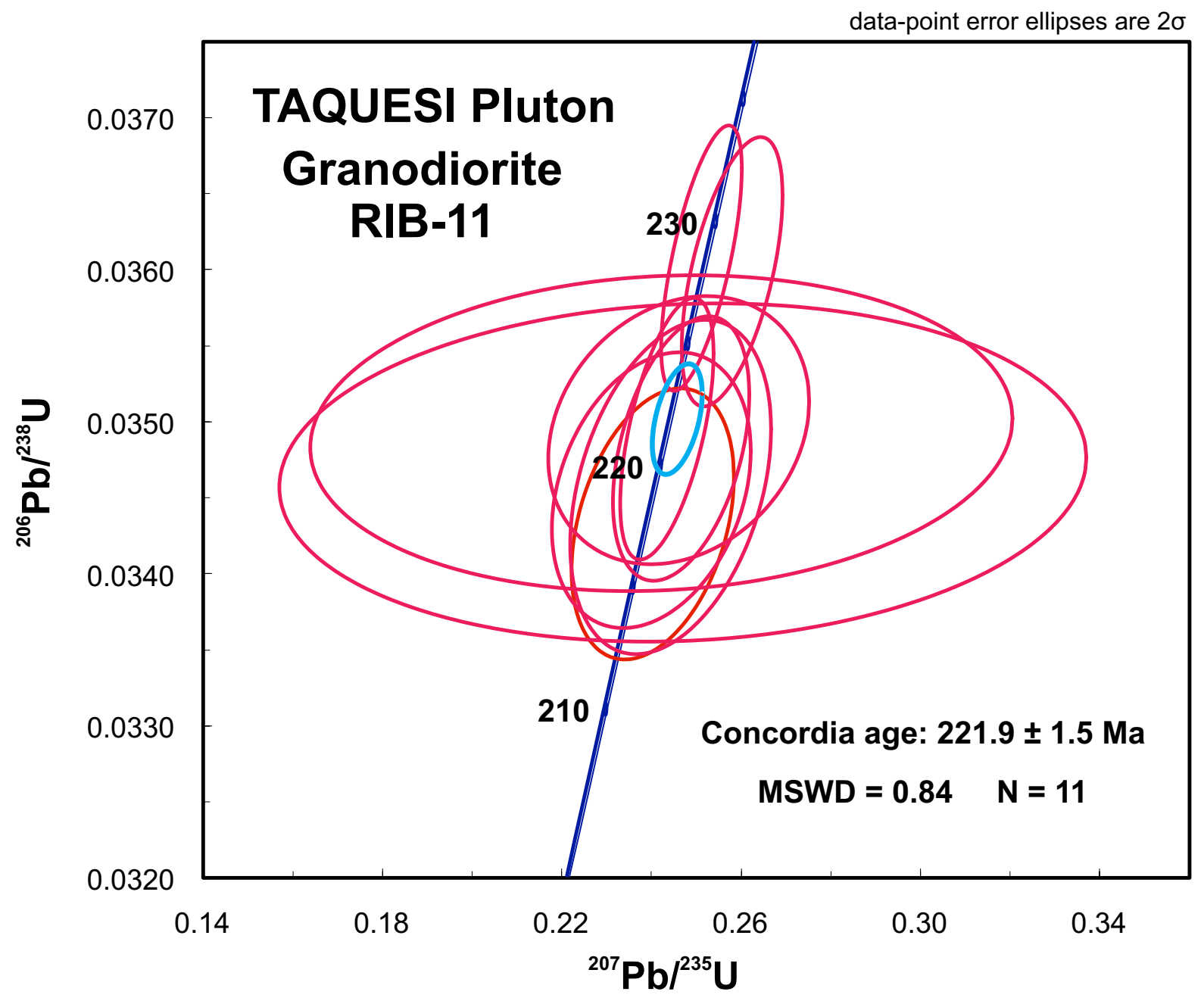

Figure 10. Concordia diagram for sample RIB-11. 
crystallization and the intrusion of the plutons of the central part of the Cordillera Real of Bolivia have occurred close to $221.5 \pm 2.0 \mathrm{Ma}$, in late Triassic times.

\section{DISCUSSION}

The different isotopic systems dealt in this paper, $\mathrm{U}-\mathrm{Pb}$ zircon, $\mathrm{Rb}$-Sr whole-rock and $\mathrm{K} / \mathrm{Ar}$ mica ages, record important data that can be used to understand the regional geological history of the Real Cordillera of Bolivia, taking into account the already known evidence described in item 2.

By far, the U-Pb SHRIMP method in zircon crystals produced the most precise ages for the granitoid plutons studied in this paper. However, regarding the intrusion time of the Cordillera Real plutons, the interpretation of the new $\mathrm{U}-\mathrm{Pb}$ SHRIMP ages is not straightforward. Only sample RIB-11 of the Taquesi pluton yielded a robust age of $221.9 \pm 1.5 \mathrm{Ma}$, which can be related to the zircon crystallization during a single magmatic pulse. However, samples RIB-2 and RIB-4 of the Huayna Potosi pluton, as shown in Figures 8 and 9, exhibited a series of grains right on the Concordia with single ages spanning more than $30 \mathrm{Ma}$. How could the ages of these zircon crystals, present in the same rock sample, span a time interval of a few tens of Ma, given that each of them seems to be perfectly characterized as formed during one given magmatic episode?
Could these different age values be all significant, revealing a series of distinct crystallization events in time, within the same original magma chamber? Could some restricted solid state $\mathrm{Pb}$ diffusion in any already crystallized zircon produce a small dislocation of its analytical point, but keeping a practically concordant situation, right over the Concordia curve?

The age measurements done at the SHRIMP were controlled by means of the Temora zircon standard, whose age is $416.8 \mathrm{Ma}$. All four samples dealt with in this paper were included in the same mount, SP-362, together with a few standard fragments. 36 Temora measurements were made in four different sessions, together with about 100 zircon measurements on grains of the RIB samples. Looking especially at the standard results, they were normal and showed an overall assigned $\mathrm{Pb} / \mathrm{U}$ external error (1 sigma) of $1.10 \%$. The odd piece of evidence, zircons with different ages in the same well crystallized granitic rock, has still to be investigated properly. A similar situation was encountered by Gillis et al. (2006), who also dated using $\mathrm{U} / \mathrm{Pb}$ SHRIMP in zircon one sample of the Huayna Potosi pluton and another from the Zongo pluton. Like in this paper, they could not obtain a unique precise age for each sample and reported an interval between 241 and $218 \mathrm{Ma}$ for the Huayna Potosi pluton, and an interval from 263 to $227 \mathrm{Ma}$ to the Zongo pluton. Moreover, in our case, inserts II and III in Figure 8 show that Concordia ages can be

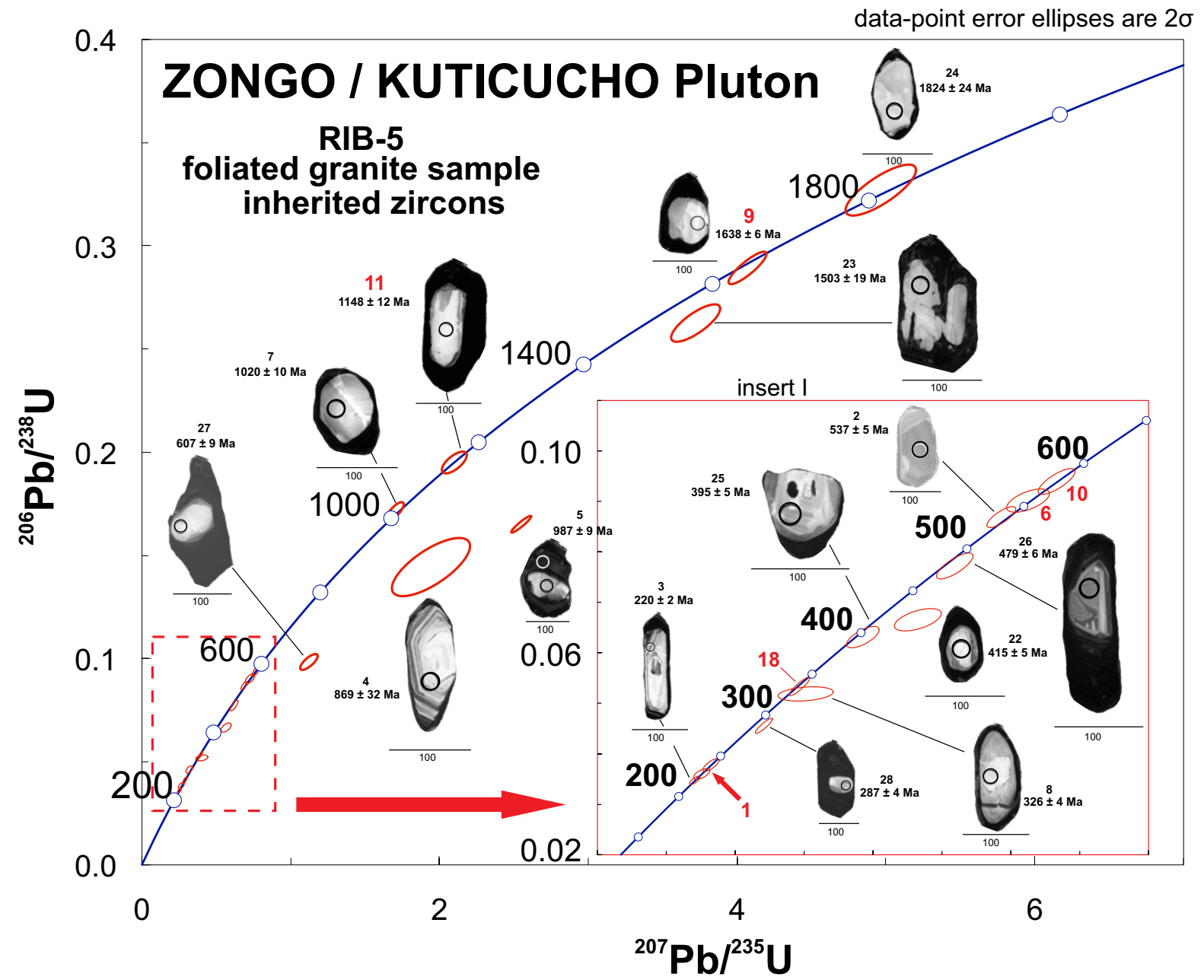

Figure 11. Concordia diagram for the measured spots of inherited zircon grains with whitish nuclei of the RIB-5 sample, and respective cathode-luminescence (CL) images. 
calculated for two different populations of the RIB-2 zircon grains $(249 \pm 3 \mathrm{Ma}$ and $222 \pm 2 \mathrm{Ma})$. In addition, inserts II and III in Figure 9 show that two Concordia ages can be calculated for two different populations of the RIB-4 grains (243 \pm $3 \mathrm{Ma}$ and $221 \pm 2 \mathrm{Ma}$ ). The age correspondence is remarkable. Considering that the two samples are located about $1 \mathrm{~km}$ apart, could that age similarities be just a coincidence?

As to sample RIB-5, as shown from its CL images, all magmatic zircon grains are either spotted metamict crystals or black structured fragments or crystals showing an inherited core and a small or large black rim. All black domains bear high uranium content, and sometimes extreme uranium content. Most likely, the black zircon crystals were formed in the youngest magmatic crystallization episode of the Zongo pluton. As already indicated in Figures 11 and 12, the calculated regressions, considering all the reverse discordant ages of the black domains, yielded unprecise ages of ca. 220 Ma. The RIB-5 sample also has many inherited grains with preserved whitish
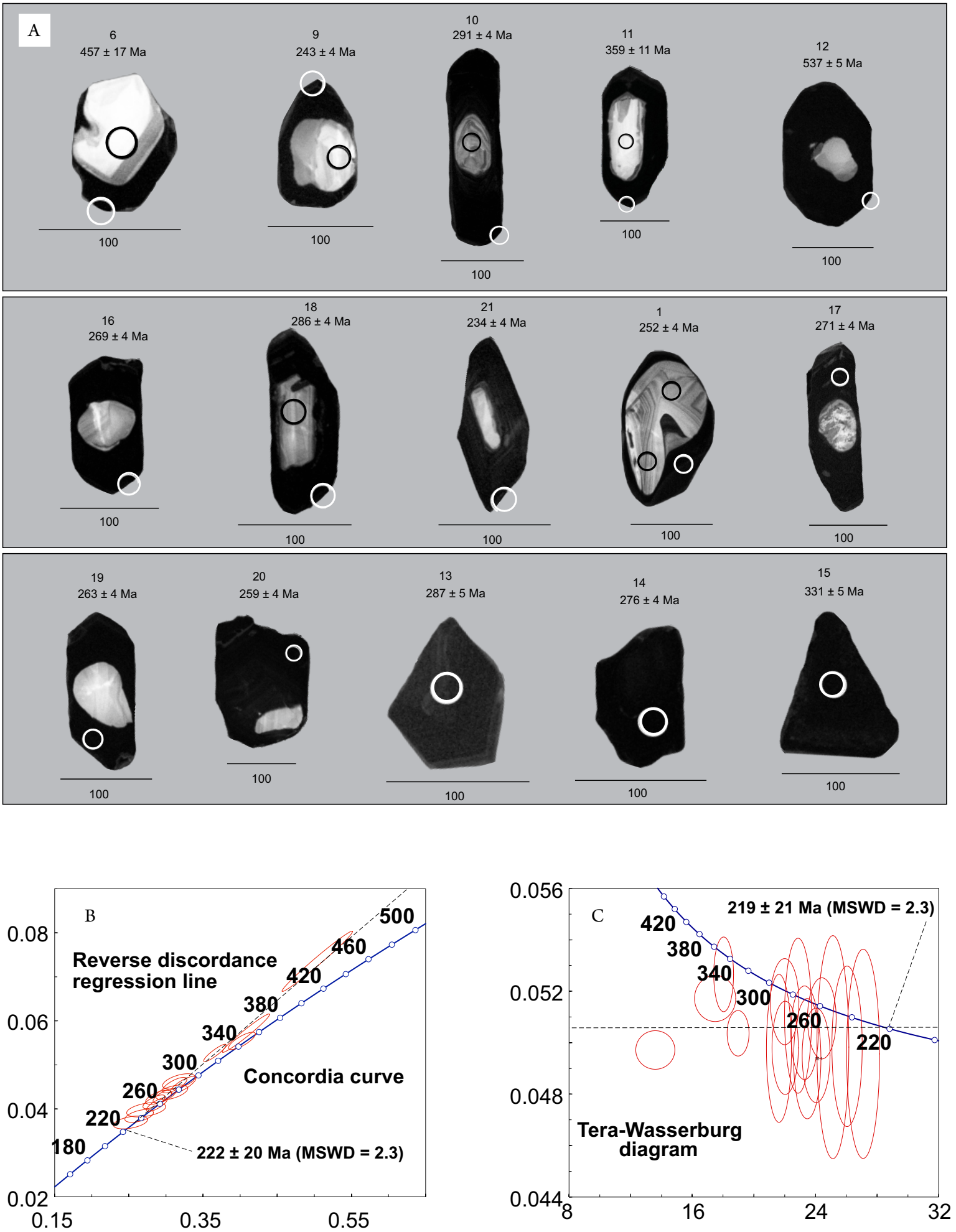

Figure 12. Concordia diagrams and cathode-luminescence (CL) images for the measured spots on black high-Uranium domains of zircon grains of the RIB-5 sample. (A) CL zircon images. (B) Concordia diagram for the black domains, showing the regressed reverse discordant analytical points. (C) Tera-Wasserburg diagram for the same black spots of Figure 12B. 
nuclei, which yielded old apparent ages, in most cases pre-Triassic. The youngest of these cores, zircon 3.1 in Table 2D, presents a faint vestige of oscillatory zones and is surrounded by high-uranium black edges. Its age of $220 \mathrm{Ma}$, identical within error to the age of the youngest correspondent grains of the Huayna Potosi and Taquesi plutons, may indicate the highest limit to the final magmatic crystallization linked to the intrusion of the Zongo pluton.

Reverse discordant zircon crystals (Wiedenbeck 1995) are difficult to interpret, and the subject is open to debate. In general, zircon losing $\mathrm{U}$ in preference to $\mathrm{Pb}$ is usually not easily accepted, because $U$ replaces $\mathrm{Zr}$ in the structural lattice of the crystals. Williams \& Hergt (2000) already asked for caution when measuring the age of high $U$ domains, and White \& Ireland (2012) considered that a reverse discordance could be due to the possibility of enhancing the emission of $\mathrm{Pb}^{+}$relative to $\mathrm{U}$, due to degradation of the zircon matrix from radiation damage. In our point of view, the anomalous $U$ enrichment in the magmatic grains of the Zongo/Kuticucho foliated granites is a clear piece of evidence for their formation during the final stage of the magmatic process affecting these granites. We will not be surprised if the age of the strong NW-SE deformation that affected the Zongo/Kuticucho granite would be synchronous with that final magmatic (or metasomatic?) episode, in which the new zircon lattices with extremely high Uranium were formed. The modal analysis of RIB-5 (Tab. 1) contains a large amount of two generations of muscovite, the younger of which may correspond to the "hydrothermal muscovite" indicated by McBride et al. (1987). It could well have been formed throughout the same hydrothermal fluids that also brought about the high uranium amount, which was included in the black metamictic zircon crystals of the pluton.

Regarding inherited zircon crystals, Table 2 shows a total of about 40 grains with pre-Triassic U-Pb SHRIMP ages in the four studied samples of the Huayna Potosi, Zongo and Taquesi plutons, which indicate the existence of previously formed zircons in the four investigated Triassic granites. Most of the age values are concordant and precise, but there are also several discordant analytical points indicating some $\mathrm{Pb}$ loss. These grains are xenocrysts formed in igneous crystallization episodes occurred in different and older magmatic chambers, in some cases much before the event that produced the final crystallization and emplacement of the Cordillera Real plutons. The inherited grains usually include a circular or elliptical core that shows a sharp whitish coloration in the CL images, in which all the SHRIMP spots were located. As already indicated, these cores were thought to be very low in Uranium due to their color, but instead they presented normal-type content, and some of them exhibited phantom traces of oscillatory zoning typical of magmatic zircon. Since such whitish cores were present in all the studied samples of the Huayna Potosi and Zongo plutons, we have attributed the vanishing of pre-existing structures, such as domains with oscillatory zoning, to the action of metasomatic fluids during a widespread regional process. This was possibly synchronous with the formation of the black overgrowth rims, as evident in sample RIB-5.
The high zircon inheritance of these plutons is most likely representative of "cold magmas" (Bachmann et al. 2007, Miller et al.2003), which are not hot enough to dissolve the inherited zircons acquired either from basement magmatic sources or from detrital material included within the Paleozoic country rocks. Looking at the bulk of inherited grains, only one is Archean, and only three others are Paleoproterozoic. Possible sources for them must be attributed to basement rocks that, in this case, may belong to some parts of the Arequipa Massif, which forms the crustal basement right below the main extensional zone of the Eastern Cordillera (Loewy et al. 2004, Ramos 2018a). Several inherited grains indicated Mesoproterozoic ages, for which the possible sources could be located in the Western part of the Amazonian Craton (Cordani et al.2000), but only a few of them are clearly related to the Grenvillian Orogeny that is widespread all along the basement of the Andean Chain (Ramos \& Alemán 2000). Neoproterozoic ages are important, and a cluster is noted close to $570-580 \mathrm{Ma}$ that is clearly related to the Brasiliano Orogeny, widespread over the Brazilian Shield at the near eastern side of the Cordillera. Granitic rocks of this orogenic cycle may have brought important material to the Paleozoic meta-sedimentary sequences that were directly intruded by the Cordillera Real studied plutons. Finally, the Paleozoic apparent ages show that a large part of the inherited crystals presented ages associated with magmatic episodes of the Andean Cordillera, where the main sources could have been granitoids formed in the Famatinian or Gondwanide orogenies.

From the U-Pb SHRIMP ages obtained in this paper, the final magmatic crystallization and the intrusion of plutons of the central part of the Cordillera Real of Bolivia most likely occurred at $221.5 \pm 2.0 \mathrm{Ma}$, in the late Triassic times. This is corroborated by the Rb-Sr isochron age shown in Figure 6 of $224 \pm 28 \mathrm{Ma}$, which, although lacking adequate precision, is concordant within error with the indicated U-Pb SHRIMP results. The five-point $\mathrm{Rb}-\mathrm{Sr}$ whole-rock isochron produced from the two-micas granite BO-9, located closely to the southern border of the Huayna Potosi pluton, yielded a ${ }^{87} \mathrm{Sr} /{ }^{86} \mathrm{Sr}$ initial ratio of $0.7103 \pm 0.0016$. This indicates that the original magma is not juvenile and shall be considered compatible with substantial crustal contamination. This is confirmed by the obvious piece of evidence consisting of large amounts of inherited zircon grains, originated from basement rocks, found in the studied samples. Moreover, considering the Rb-Sr systematics related to the six measured samples from the Zongo/ Kuticucho pluton (Fig. 6), taken from strongly deformed outcrops, the "errorchron" with a $186 \pm 25 \mathrm{Ma}$ age and a very high ${ }^{87} \mathrm{Sr} /{ }^{86} \mathrm{Sr}$ initial ratio of about $0.731 \pm 0.008$ is most likely related to a perturbation in their $\mathrm{Rb} / \mathrm{Sr}$ ratios. Possibly, this occurred somewhat later in respect to the formation of the rock and will be considered below, when dealing with the interpretation of the available K-Ar ages.

Considering the $\mathrm{Rb}$ - $\mathrm{Sr}$ determinations on the four samples of metapelitic sedimentary rocks (BO-4 to 7) that belong to the early Paleozoic Amutara and Cancañiri formations, collected at the SW edge of the Huayna Potosi pluton, they may highlight the existence of an important tectonic event in the regional geological history. Figure 6 
brings their $\mathrm{Rb}-\mathrm{Sr}$ whole-rock isochron age of $344 \pm 38 \mathrm{Ma}$, with an initial ${ }^{87} \mathrm{Sr} /{ }^{86} \mathrm{Sr}_{\mathrm{i}}$ ratio of 0.72 , and white mica is probably the main mineral constraining the $\mathrm{Rb} / \mathrm{Sr}$ whole-rock ratio. The obtained age, although exhibiting a very large experimental error, shall be considered as a correspondence to a resetting during the widespread intra-plate early Gondwanide orogeny, affecting these rocks during the early Carboniferous (Dalmayrac et al. 1980). Important regional tectonic episodes of this age, represented by intra formational discordances and crenulated foliation, are described in the Central Andes of Perú and Bolivia (Mégard et al. 1971, Tawackoli et al. 1996).

Table 4 brings $12 \mathrm{~K}$-Ar measurements measured long ago (Cordani et al. 1980), whose ages are presented in this paper for the first time. Many other K-Ar determinations, referred in Evernden et al. (1977), McBride et al. (1983, 1987), Farrar et al. (1990), Kennan et al. (1995) and Gillis et al. (2006), are available at present, totalizing about $100 \mathrm{~K}$-Ar ages for rocks of the central part of the Cordillera Real. A few of them was obtained applying the Ar-Ar method. The great majority used micas, and in many cases biotite and muscovite were measured from the same rock specimen. In general, the overall results are coherent and can be interpreted in terms of critical temperature for argon retention in micas.

For muscovite and biotite belonging to the Huayna Potosi granite, in the southern part of the Zongo profile (Fig. 3), the measured K-Ar apparent ages resulted between 195 and $218 \mathrm{Ma}$. McBride et al. (1987) also analyzed a muscovite that yielded an Ar/Ar plateau of $214 \mathrm{Ma}$ for this same pluton. Moreover, for the small Unduavi stock, at the eastern side of the Huayna Potosi pluton, and for the Chacaltaya stock at the southern side, a few micas yielded K/Ar ages between 202 and $213 \mathrm{Ma}$. Although less precise, these apparent ages, which must be attributed to the cooling of the pluton below $300^{\circ} \mathrm{C}$, are not very different from the $\mathrm{U}-\mathrm{Pb}$ zircon or $\mathrm{Rb}-\mathrm{Sr}$ ages.

However, proceeding northerly and descending along the Zongo river towards the Bolivian Amazonian forest, the apparent K-Ar ages, either of muscovite or biotite, decrease from SW to NE, as it is clear when reaching the Kuticucho and Sainani facies of the Zongo pluton. Such systematic Ar loss was already recognized by McBride et al. (1987), who showed the decrease of apparent ages of muscovite and biotite from close to $200 \mathrm{Ma}$ down to less than $100 \mathrm{Ma}$. This is confirmed in Table 4, in which the biotite BO-10 at the Huayna Potosi yielded ca. $200 \mathrm{Ma}$, the muscovite at Kuticucho ca. $130 \mathrm{Ma}$, and the muscovite at Sainani ca. $78 \mathrm{Ma}$. The gradual decrease continues until about $39 \mathrm{Ma}$ (Oligocene), corresponding to a well-defined Ar-Ar plateau age of the biotite CR-370 from a granitic rock of the Sainani facies of the Zongo pluton (McBride et al. 1987). These authors, as well as Farrar et al. (1988) and Gillis et al. (2006), attributed this situation to the onset of a unique regional thermal event that opened the $\mathrm{K} / \mathrm{Ar}$ isotopic system in the early Oligocene, related to the back-thrusting dynamics of the Andean orogeny and the associated ZongoSan Gaban thermal effect (Ramos 2018a).

\section{CONCLUSIONS}

The geochronological data available for the Huayna Potosí, Zongo and Taquesi plutons of the Real Cordillera of Bolivia are a relevant contribution to the assessment of the geological history of that region. The $\mathrm{Rb}$-Sr ages of the early Paleozoic metasedimentary rocks of the Amutara and Cancañiri formations indicate the time for the tectonic activities associated with the early Gondwanide orogeny. The U-Pb zircon ages of the mentioned granitic plutons confirm their Triassic intrusion age associated with the post-tectonic magmatism of the late Gondwanide orogeny, within an important extensional tectonic zone linked to the Pangea disruption. Finally, the K-Ar and Ar-Ar ages of micas indicate the action in the Oligocene of a strong thermal episode of the Andean orogeny, the Zongo-San Gabán effect, related to the formation of a regional "inner arc".

Moreover, in this paper, some factual pieces of evidence raised a few scientific questions that shall be considered in the future:

- The numerous inherited zircon grains encountered within the Huayna Potosi and Zongo samples, no matter their age, although showing normal uranium content, present a whitish coloration. A few of them have faint traces of light grey oscillatory zones and many show high uranium black rims. Most likely, they were probably decolored at the same time as the black rims were formed, during the final episode of the magmatic crystallization of the Triassic plutons. Such geochemical process shall be investigated and clarified;

- For the two dated samples of the Huayna Potosi pluton, as shown in Figures 8 and 9, a final crystallization age was not clearly indicated by one specific cluster of analytical points, considering that a unique Concordia age could not be obtained. The calculated single ages of many zircon grains plotted right on the Concordia curve, forming a continuous line corresponding to a time interval spanning something like 30-40 Ma. Regarding both RIB-2 and RIB-4, two different ages were calculated, using two selected clusters of analytical points. The younger cluster, whose age was close to $221 \mathrm{Ma}$ in both cases, was significant for the final magmatic crystallization of the pluton;

- Finally, for the the Zongo/Kuticucho foliated pluton, the black domains of sample RIB-5, presenting very high uranium content and yielding systematically reverse discordant ages, are interpreted as due to anomalous uranium enrichment during the late stage magmatic processes affecting that rock. The calculated regressions yielded unprecise ages near $220 \mathrm{Ma}$, which would agree with the regional geological history. However, as indicated in the discussion, the generation of reverse discordant zircon grains, linked to ion mobility and disturbance of the $\mathrm{U} / \mathrm{Pb}$ ratio, is still subject to debate. In the present case, the correlation with extreme uranium content is evident, and perhaps future researches using our Zongo/Kuticucho zircon crystals will be able to bring some new light towards a better interpretation of the phenomenon. 


\section{ACKNOWLEDGMENTS}

We thank the Institute of Geosciences (IGc) of the USP for their help given in 1978 for the sample preparation and isotopic analyses done in the samples collected by the senior author in the Bolivian Andes. Also, we are thankful for the personnel of the Proyecto Cordillera of GEOBOL who guided the field trip made at that time along the Zongo River. On the work with the samples collected recently by the second author, we thank the same institute for giving us the opportunity to use the facilities of the SHRIMP and LA-ICP-MS laboratories. Colleagues of the Carrera de Geología and Instituto de Investigaciones Geológicas y del Medio Ambiente (IGEMA) of the UMSA, La Paz, Bolivia, for their field work collaboration, support and advice. The technicians of the IGc-USP and the IGEMA-UMSA were of great help in the preparation of the analyzed samples. We would like to thank Mark Fanning for his help in the discussion related to the U-enrichment of zircon.

\section{ARTICLE INFORMATION}

Manuscript ID: 20190016. Received on: 03/05/2019. Approved on: 05/02/2019.

U. G. C. wrote the first draft of the manuscript and finalized it after revision by the co-authors; he was part of the SHRIMP analyses; compiled and interpreted the $\mathrm{Rb}-\mathrm{Sr}$ and $\mathrm{K}-\mathrm{Ar}$ ages made long ago by himself. This article is planned to be part of the author A. R. I. Doctorate. A. R. I. provided geological data on the Cordillera Real; prepared all figures and tables of the manuscript; was part of the SHRIMP analyses and improved the manuscript through corrections and suggestions. K. S. provided support and supervision to the SHRIMP analyses; wrote the chapter on methodology; contributed to the interpretation of the U-Pb zircon ages and improved the MS through corrections and suggestions.. Competing interests: The authors declare no competing interests.

\section{REFERENCES}

Ahlfeld F. \& Schneider-Scherbina A. 1964. Los yacimientos minerales y de hidrocarburos de Bolivia. La Paz, Departamento Nacional de Geologia, Ministerio de Minas y Petroleo, 388 p. (Boletín DENAGEO 5).

Amaral G., Cordani U.G., Kawashita K., ReynoldsJ.H. 1966. Potassium-argon dates of basaltic rocks from Southern Brazil. Geochimica et Cosmochimica Acta, 30(2):159-189. http://dx.doi.org/10.1016/0016-7037(66)90105-0

Ávila W.A. 1990. Tin-bearing granites from the Cordillera Real, Bolivia; A petrological and geochemical review. In: Kay S.M. \& Rapela C.W. (Eds.). Plutonism from Antarctica to Alaska. America, Geological Society of America, Special paper 241, p. 145-159.

Bachmann O., Miller C.F., de Silva S.L. 2007. The volcanic-plutonic connection as a stage for understanding crustal magmatism. Journal of Volcanology and Geothermal Research, 167(1-4):1-23. http://doi. org/10.1016/j.jvolgeores.2007.08.002

CGMW (Commission of the Geological Map of the World). 2019. Cordani, U.G., Ramos, V.A., (Coordinators). Tectonic Map of South America, 2nd edition, scale 1:5000000.

Cordani U.G., Iyer S.S. 1979. Geochronological investigation on the Precambrian granulitic terrain of Bahia, Brazil. Precambrian Research, 9(34):255-274. https://doi.org/10.1016/0301-9268(79)90006-8

Cordani U.G., Kawashita K., Cortez G. 1980. Chronology of the tectonomagmatic events of the Cordillera Real of Bolivia. In: International Geological Congress, 26., Paris. Abstracts ..., p. 32.

Cordani U.G., Sato K., Teixeira W., Tassinari C.C.G., Basei M.A.S. 2000. Crustal evolution of the South American platform. In: Cordani U.G., Milani E.J., Thomaz-Filho A., Campos D.A. (Eds.), Tectonic evolution of South America: Rio de Janeiro, Brazil, 31st International Geological Congress, p. 19-40.

Dalmayrac B., Laubacher G., Marocco R., Martinez C., Tomasi P. 1980 La Chaine Hercynienne d'Amerique du Sud. Structure et evolution d'une orogène intracratonique. Geologische Rundschau, 69(1):1-21. http://dx.doi. org/10.1007/BF01869020

Dorbath C., Granet M., Poupinet G., Martinez C. 1993. A teleseismic Study of the Altiplano and the Eastern Cordillera in Northern Bolivia: New Constraits on a Lithospheric Model. Journal of Geophysical Research, 98(B6):9825-9844. https://doi.org/10.1029/92JB02406

Evernden J.F., Kriz S.J., Cherroni M.C. (1977). Potassium-argon ages of some Bolivian rocks - a discussion. Economic Geology, 72:1042-1061.

Farrar E., Clark A.H., Heinrich S.M. 1990. The Age of the Zongo Pluton and the Evolution of the Zongo San Gaban Zone in the Cordillera Real,
Bolivia. In: Symposium international “Géodynamique andine”. Résumés des communications, p. 171-174.

Gillis R.J., Horton B.K., Grove M. 2006. Thermochronology, geochronology, and upper crustal structure of the Cordillera Real: Implications for Cenozoic exhumation of the central Andean plateau. Tectonics, 25(6):1-22. http:// doi.org/10.1029/2005TC001887

Jiménez N. \& López-Velásquez S. 2008. Magmatism in the Huarina belt, Bolivia, and its geotectonic implications. Tectonophysics, 459(1-4):85-106. http://doi.org/10.1016/j.tecto.2007.10.012

Kennan L., Lamb S., Rundle C. 1995. K-Ar dates from the Altiplano and Cordillera Oriental of Bolivia: implications for stratigraphy and tectonics. Journal of South American Earth Sciences, 8(2):163-186. https://doi. org/10.1016/0895-9811(95)00003-X

Loewy S.L., Connelly J.N., Dalziel I.W.D. 2004. An orphaned basement block: The Arequipa-Antofalla Basement of the central Andean margin of South America. Bulletin of the Geological Society of America, 116(1-2):171187. http://doi.org/10.1130/B25226.1

Ludwig K.R. 2003. Isoplot 3: A Geochronological Toolkit for Microsoft Excel. Berkeley, Berkeley Geochronology Center Special Publication, no. 4.

McBride S.L., Robertson R.C.R., Clark A.H., Farrar E. 1983. Magmatic and Metallogenetic Episodes in the Northern Tin Belt, Cordillera Real. Bolivia. Geologische Rundschau, 72(2):685-713.

McBride S.L., Clark A.H., Farrar E., Archibald D.A. 1987. Delimitation of a cryptic Eocene tectono-thermal domain in the Eastern Cordillera of the Bolivian Andes through K-Ar dating and 40Ar-39Ar step-heating. Journal of the Geological Society, 144(2):243-255. https://doi.org/10.1144/ gsjgs.144.2.0243

McQuarrie N. 2002. The kinematic history of the central Andean foldthrust belt, Bolivia: Implications for building a high plateau. Bulletin of the Geological Society of America, 114(8):950-963. http://doi. org/10.1130/0016-7606(2002)114<0950:TKHOTC>2.0.CO;2

Mégard F., Dalmayrac B., Laubacher G., Marocco R., Martinez C., Paredes J., Tomasi P. 1971. Le chaine Hercynienne au Pérou et en Bolivie Premiers Résultats. Cahiers Orstom, III(1):5-44. Série Géologie.

Miller C.F., McDowell S.M., Mapes R.W. 2003. Hot and cold granites: Implications of zircon saturation temperatures and preservation of inheritance. Geology, 31(6):529-532. http://doi. org/10.1130/0091-7613(2003)031<0529:HACGIO>2.0.CO;2 
Miskovic A., Schaltegger U., Chew D. 2009. Carboniferous plutonism along the Eastern Peruvian Cordillera: Implications for the Late Paleozoic to Early Mesozoic Gondwanan tectonics. In: International Symposium on Andean Geodynamics, 6., Barcelona. Extended Abstracts ..., p. 508-511.

Mpodozis C. \& Kay S.M. 1992. Late Paleozoic to Triassic evolution of the Gondwana margin: Evidence from Chilean Frontal Cordilleran batholiths $\left(28^{\circ} \mathrm{S}\right.$ to $\left.31^{\circ} \mathrm{S}\right)$. Geological Society of America Bulletin, 104(8):999-1014.

Ramos V.A. 2009. Anatomy and global context of the Andes: Main geologic features and the Andean orogenic cycle. In: Kay S.M., Ramos V.A., Dickinson W.R. (Eds.), Backbone of the Americas: Shallow Subduction, Plateau Uplift, and Ridge and Terrane Collision. America: Geological Society of America, p. 31-65. (Memoirs, v. 204). http://doi. org/10.1130/2009.1204(02)

Ramos V.A. 2018a. Tectonic Evolution of the Central Andes: From Terrane Accretion to Crustal Delamination. In: Zamora Valcarce G., McClay K., Ramos V.A. (Eds.). Petroleum Basins and Hydrocarbon Potential of the Andes of Peru and Bolivia. United States, American Association of Petroleum Geologists, p. 1-34. http://doi.org/10.1306/13622115M1172855

Ramos V.A. 2018b. The Famatinian orogeny along the protomargin of western Gondwana. Evidence of a nearly continuous Ordovician magmatic arc between Venezuela and Argentina. In: Folguera A., Contreras Reyes E., Heredia N., Encinas A., B. Iannelli S., Oliveros V., M. Dávila F., Collo G., Giambiagi L., Maksymowicz A., Iglesia Llanos M.P., Turienzo M., Naipauer M., Orts D., D. Litvak V., Alvarez O., Arriagada C. (Eds.). The evolution of the Chilean-Argentinean Andes. New York: Springer, p. 154-184. (Springer Earth System Sciences).

Sato K., Tassinari C.C.G., Basei M.A.S., Siga Jr. O., Onoe A.T., De Souza M.D. 2014. Sensitive High Resolution Ion Microprobe (SHRIMP IIe/ MC) of the Institute of Geosciences of the University of São Paulo, Brazil: Analytical method and first results. Geologia USP - Série Cientifica, 14(3):318. http://doi.org/10.5327/Z1519-874X201400030001

Sempere T. 1995. Phanerozoic evolution of Bolivia and adjacent regions. In: Tankard A., Suárez S. R., Welsink H. (Eds.). Petroleum basins of South
America: AAPG Memoir 62. America: Geological Society of America Memoirs, p. 207-230.

Sergeotecmin 2011. Carta Geológica de Bolivia. Hoja Charazani 584. Publicación SGTM-Serie I-CGB-62. Scale 1:100000. Bolivia: Servicio Geológico de Bolivia.

Spikings R., Reitsma M.J., Boekhout F., Mišković A., Ulianov A., Chiaradia M., Gerdes A., Schaltegger U. 2016. Characterisation of Triassic rifting in Peru and implications for the early disassembly of western Pangaea. Gondwana Research, 35:124-143. http://doi.org/10.1016/j.gr.2016.02.008

Sugaki A., Shimada N., Ueno H., Kano S. 2003. K-Ar ages of tin-polymetallic mineralization in the Oruro mining district, central Bolivian tin belt. Resource Geology, 53(4):273-282.

Tawackoli S., Kley J., Jacobshagen V. 1996. Evolución tectónica de la Cordillera Oriental del Sur de Bolivia. In: XII Congreso Geológico de Bolivia, 12., Tarija. Memorias..., p. 91-96, Tarija.

White L.T. \& Ireland T.R. 2012. High-uranium matrix effect in zircon and its implications for SHRIMP U-Pb age determinations. Chemical Geology, 306307:78-91. http://doi.org/10.1016/j.chemgeo.2012.02.025

Wiedenbeck M. 1995. An example of reverse discordance during ion microprobe zircon dating: An artifact of enhanced ion yields from a radiogenic labile $\mathrm{Pb}$. Chemical Geology, 125(3-4), 197-218. http://doi. org/10.1016/0009-2541(95)00072-T

Williams I.S. 1998. U-Th-Pb geochronology by ion microprobe. In: McKibben M.A., Shanks I., Ridley W.C.P., Ridley W.I. (Eds.). Application of Microanalytical Techniques to Understanding Mineralizing Process. Reviews in Economic Geology. United States: Society of Economic Geologists, 7:1-35.

Williams I.S. \& Hergt J.M. 2000. U-Pb dating of Tasmania dolerites: A Cautionary Tale of SHRIMP Analyses of High-U Zircon. In: Woodhead J.D., Hergt J.M., Noble W.P. (Eds.). Beyond 2000: New Frontiers in Isotope Geoscience, Lorne, 2000. Abstracts and Proceedings ..., 185-188.

York D. 1968. Least Squares Fitting of a Straight Line with Correlated Errors. Earth and Planetary Science Letters, 5:320-324. https://doi.org/10.1016/ S0012-821X(68)80059-7 